\title{
Mass concentration of Hirnantian cephalopods from the Siljan District, Sweden; taxonomy, palaeoecology and palaeobiogeographic relationships
}

\author{
Björn Kröger*, ${ }^{*}$, Jan Ove R. Ebbestad ${ }^{2}$, Annette E. S. Högström ${ }^{3}$ and Åsa M. Frisk ${ }^{4}$ \\ ${ }^{1}$ Museum für Naturkunde Berlin, Invalidenstraße 43, 10115 Berlin, Germany. E-mail: bjoekroe@gmx.de \\ ${ }^{2}$ Museum of Evolution, Uppsala University, Norbyvägen 16, SE-752 36 Uppsala, Sweden. E-mail: jan-ove.ebbestad@evolmuseum.uu.se; \\ anette.hogstrom@pal.uu.se \\ ${ }^{3}$ Tromsø University Museum, Naharat Sciences, N-9037 Tromsø, Norway. E-mail: anette.hogstrom@uit.no \\ ${ }^{4}$ Department of Earth Sciences, Palaeobiology, Villavägen 16, SE-752 36 Uppsala, Sweden. E-mail: asa.frisk@geo.uu.se
}

\begin{abstract}
Received 10 March 2010

Accepted 27 August 2010

Published 21 February 2011

\section{Key Words}

Nautiloidea

Orthocerida

Boda Limestone

Glisstjärn Formation

cephalopod limestone

The Hirnantian Glisstjärn Formation (Normalograptus persculptus graptolite Biozone) is a succession of limestones and shales onlapping the Katian Boda Limestone in the Siljan District, Sweden. It contains a conspicuous, up to several decimeter thick bed densely packed with bipolarly oriented, orthoconic cephalopod conchs that can reach lengths of more than $120 \mathrm{~cm}$. Conch fragmentation, bioereosion and the generally poor preservation of the conchs indicate time averaging and the conchs are tentatively interpreted as beached, and a result of winnowing. Ten nautiloid species were collected from the Glisstjärn Formation of which five are new: Dawsonoceras gregarium n. sp., Discoceras siljanense n. sp., Isorthoceras dalecarlense n. sp., Retizitteloceras rarum gen. et sp. n., and Transorthoceras osmundsbergense gen. et sp. $\mathrm{n}$. The non-endemic taxa in most cases are known from elsewhere in Baltoscandia, except one species which is known from Siberia, and North America respectively. Proteocerid orthoceridans dominate the association, of which T. osmundsbergense is the predominant species. Oncocerids are diverse but together with tarphycerids very rare. Notable is the lack of many higher taxa, that are typical for other Late Ordovician shallow water depositional settings. Based on the taxonomical composition of the cephalopod mass occurrence it is interpreted as an indicator of eutrophication of the water masses in the area.
\end{abstract}

\section{Introduction}

The latest Ordovician succession of the Siljan district, central Sweden, is renowned for the massive Boda Limestone mud mounds with their highly diverse conchy fauna (Ebbestad \& Högström 2007a). The age of the Boda Limestone has been disputed but recently it became clear that the mound facies and the unconformably overlying Glisstjärn Formation are of Hirnantian age (Schmitz \& Bergström 2007; Suzuki et al. 2009). These sections in Siljan preserve a diverse, well-preserved fauna through a time interval spanning the twophased end-Ordovician extinction event. The initial phase of the extinction is potentially recorded at the top of the Boda Limestone (Normalograptus extraordi- narius graptolite Biozone), extending into the second phase within the Glisstjärn Formation (N.persculptus graptolite Biozone).

Recently a remarkable horizon of densely packed cephalopods in the Glisstjärn Formation was recognized in the Osmundsberget quarry (Ebbestad et al. 2007; Schmitz \& Bergström 2007; Figs 1, 2). A large bedding surface of this horizon is exposed in one part of the quarry (locality Osmundsberget 1, see below). A similar cephalopod horizon is also recognized in Kallholn quarry (Figs 1,2). Ten nautiloid species were collected from the cephalopod bed, of which five are new: Dawsonoceras gregarium n. sp., Discoceras siljanense n. sp., Isorthoceras dalecarlense n. sp., Retizitteloceras rarum gen. et n. sp., and Transorthoceras osmundsber-

\footnotetext{
* Corresponding author
} 

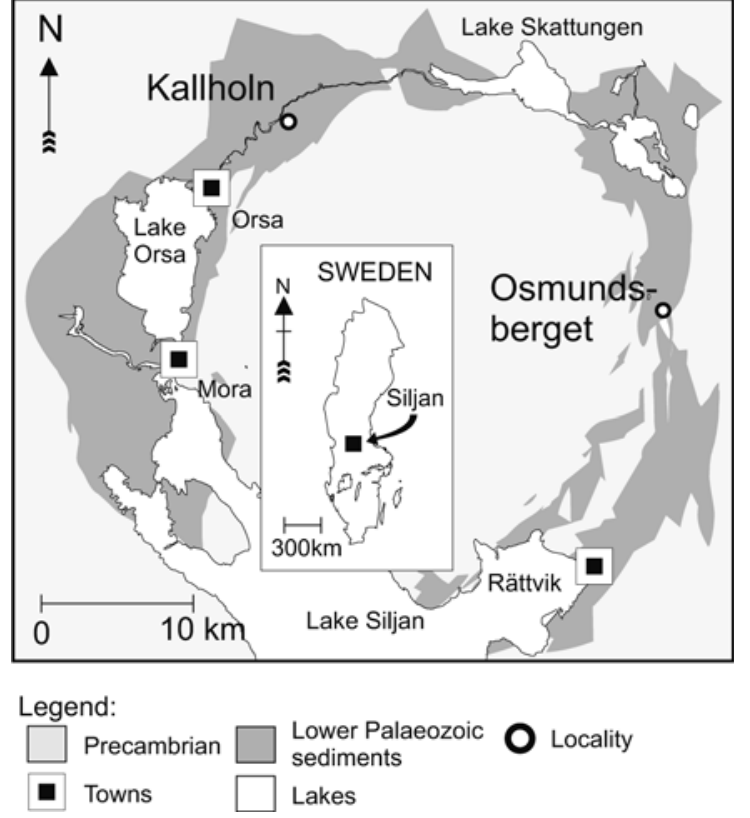

Figure 1. Map of the Siljan astroblem with the Lower Palaeozoic sediments preserved in the ring structure. The localities Kallholn and Osmundsberget quarry are marked (modified from Ebbestad \& Högström 2007b, fig. 52a).

gense gen. et $\mathrm{n}$. sp. The present paper expands on a similar study by Kröger (2007) from largely coeval beds in Estonia, where the influence of Hirnantian cephalopod taxa in shaping the post-Ordovician evolutionary history of the group was highlighted. A plethora of nautiloid cephalopods are found in the Katian Boda Limestone itself, but despite a number of primary taxonomic papers many taxa remain to be described (Angelin \& Lindström 1880; Mutvei 1957; Frye 1982, 1987; Niko 2008).

Institutional abbreviation. PMU - Paleontological collections, Museum of Evolution, University, Uppsala, Sweden.

\section{Geological setting and material}

The Siljan ring astroblem in central Sweden preserves early Ordovician - Silurian sedimentary rocks, where the Ordovician succession is mainly composed of highly condensed limestone (see Ebbestad \& Högström 2007a), In the Late Ordovician strata large carbonate mud mounds are developed, namely the Kullsberg Limestone (early Katian) and the Boda Limestone (late Katian - Hirnantian). The Ordovician succession is terminated by the limestones and shales of the Glisstjärn Formation. Recently Schmitz \& Bergström (2007) recorded the Late Ordovician isotope excursion (HICE) in the upper $\sim 24 \mathrm{~m}$ of the Boda Limestone and the Glisstjärn Formation at Osmundsberget quarry (Fig. 2). The section spans the Hirnantian (Normalograptus extraordinarius - N. persculptus graptolite biozones) albeit with the first Hirnantian lowstand unconformity (named HA by Bergström et al. 2006) between the two units. A hiatus at the top of the Glisstjärn Formation (HB sensu Bergström et al. 2006) reflects a period of non-deposition/ and or erosion before the Silurian (Aeronian) shale of the Kallholn Formation commences.

Presently the Glisstjärn Formation is only recognized in outcrops in the Osmundsberget and Kallholn quarries (Fig. 1). The stratotype in the Kullsberg quarry, where the unit measures 13 m (Thorslund 1935) no longer exists. At Osmundsberget the upper part of the unit is found in two localities, Osmundsberget 1 and Osmundsberget 5 (locality names follow those of Ebbestad \& Högström 2007b; Fig. 2), onlapping the Boda Limestone. The mound and associated strata are nearly vertical with the youngest beds to the northwest. At Osmundsberget 1 (Figs 2A, 2B), situated at the southwestern entrance of the quarry, about $3 \mathrm{~m}$ of the unit is exposed. Here it unconformably overlies the massive micritic carbonates of the Katian Boda Limestone Core Member of Suzuki et al. (2009; see also Rasmussen pers. comm.). The upper surface of the mound is uneven, causing a variable thickness of the Glisstjärn Formation. However, the beds are subparallel and viewed in conjunction with the facies of the mound at this site and the general topography suggest that it is close to the apex of the mound. The second locality, Osmundsberget 5 , is located at the northern entrance of the quarry (Figs 2A, 2C). This is the section studied by Schmitz \& Bergström (2007). The Glisstjärn beds are exposed on both the east and west flanks of the entrance and are about $3.25 \mathrm{~m}$ thick in the eastern exposure. The unit onlaps with a $10^{\circ}$ angular unconformity the stratified micritic limestone of the Hirnantian Upper Boda Limestone Member (as defined by Suzuki et al. 2009). Silurian shales of the Kallholn Formation overlie the Glisstjärn beds at this locality. Here, the deposit is also close to the apex although on the opposite side of the apex relative to Osmundsberget 1 .

The cephalopod concentration in the Glisstjärn Formation is best exposed at Osmundsberget 1 , where it occurs as a bedding plane about $1.5 \mathrm{~m}$ above the top of the Boda Limestone Core Member (Fig. 2). The exposure reveals large, densely packed, straight nautiloid conchs that can reach a length of about $120 \mathrm{~cm}$. Two such horizons are present within $10 \mathrm{~cm}$ of each other. A prominent bipolar distribution is evident. However, the taphonomy of the deposit is treated in a future paper. At Osmundsberget 5 one cephalopod bed is recognized, and though exposure at the bedding plane is restricted it is clear that the density of conchs is less and a bipolar distribution is not immediately evident.

At the Kallholn quarry the Glisstjärn Formation is exposed in the southern flank of the mound near the entrance of the quarry (Fig. 2D). Two exposures are accessible at the entrance, but only the southernmost (Kallholn 1) exposes an undisturbed section from the top of the Upper Boda Limestone Member to the Llandovery shale of the Kallholn Formation. The Ordovician-Silurian boundary is also exposed at the northern side of the quarry entrance (Kallholn 2; Fig. 2D), but here the Kallholn Formation directly onlaps the Upper Boda Limestone Member. At Kallholn 1, the Glisstjärn Formation is $2.20 \mathrm{~m}$ thick, showing a similar succession to that of the section in Osmundsberget 5, also onlapping the Upper Boda Limestone Member. The cephalopod bed occurs at the bottom of the Glisstjärn Formation, and is $25 \mathrm{~cm}$ thick. Numerous cephalopods are evident in cross section, with the largest diameter measured being $3.5 \mathrm{~cm}$. Above the cephalopod bed follow $155 \mathrm{~cm}$ of mudstone with intercalated limestone beds and finally $50 \mathrm{~cm}$ of more massive limestone below the Silurian shales.

With the exception of a few specimens found at Osmundberget 5, the material used in this study originates from the cephalopod bed at Osmundsberget 1 .

\section{Palaeobiogeographic relationships of the fauna}

Of the ten species described from the Glisstjärn Formation, five are known from elsewhere. Most of the nonendemic species are known from other regions in Baltoscandia: The oncocerid Beloitoceras heterocurvatum Strand, 1934 is known from the late Katian of Norway, Estonia and the Siljan District in Sweden (Strand 1934; 


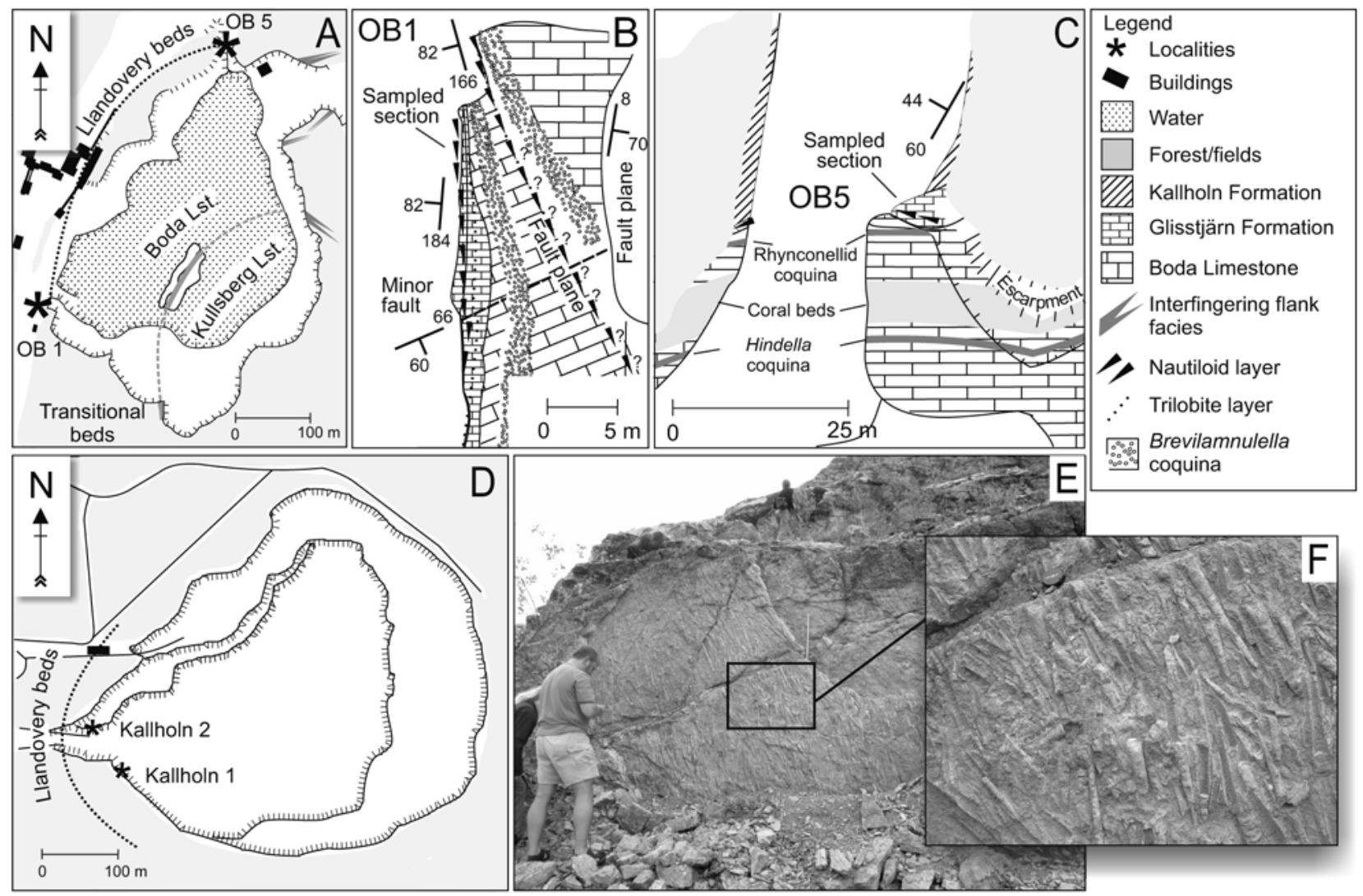

G
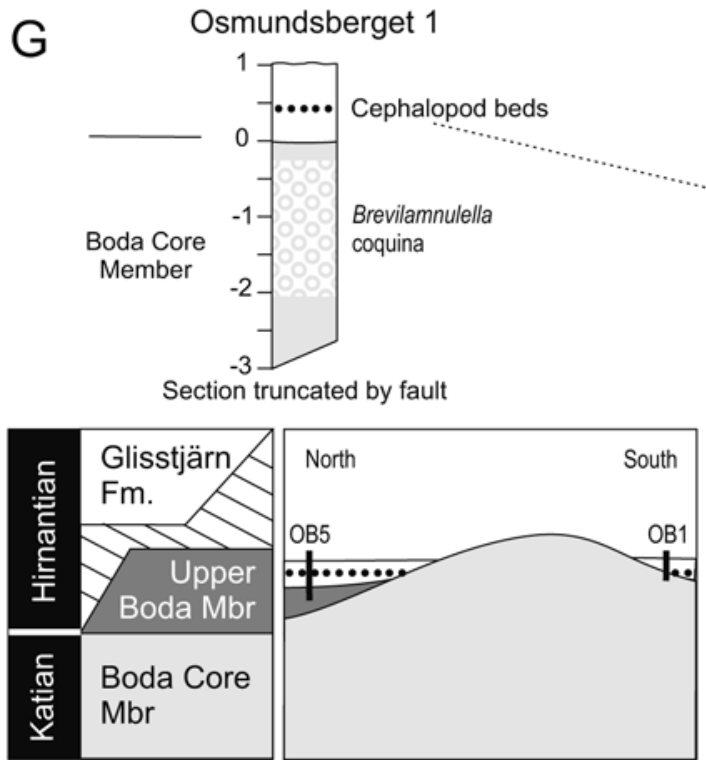

Osmundsberget 5

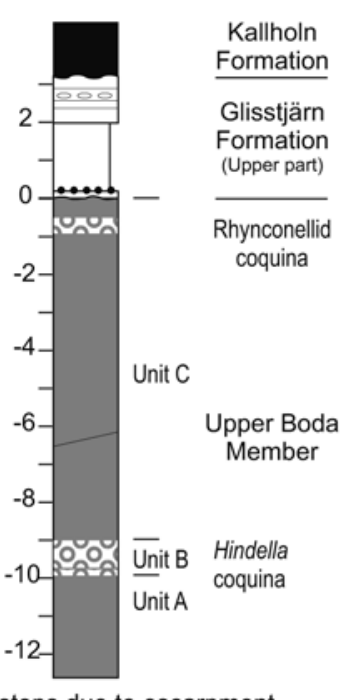

Figure 2. Detailed maps of the localities discussed in the text. A. Osmundsberget quarry (topographical map sheet Rättvik $14 \mathrm{~F}$ SV). Overview with Osmundsberget 1 (OB1) and Osmundsberget 5 (OB5) marked; B. Osmundsberget 1 (UTM WH10654 68128), where the main cephalopod wall is found; C. Osmundsberget 5 (UTM WH10886 68478), where the most complete section is found. This is the section discussed by Schmitz \& Bergström (2007); D. Kallholn quarry (topographical map sheet Mora 14E NO). The Glisstjärn facies is present at Kallholn 1 (UTM VH85383 81344), while missing at Kalholn 2, where Silurian shale directly onlap the Upper Boda Member of the Boda Limestone (UTM VH84371 81411); E. Overview of the cephalopod wall at OB1. The scale bar in the picture is $50 \mathrm{~cm}$; F. Detail of the cephalopod wall at OB1; G. Stratigraphy and tentative cross section of the Boda Limestone mound at Osmundsberget quarry with positions of sections indicated. The drawing is not to scale. The two sections at Osmundsberget quarry show key fossil horizons and facies units. Maps are modified from Ebbestad \& Högström (2007b), while stratigraphical overview is modified from Suzuki et al. (2009) and Rasmussen et al. (2010). 
Frye 1987). Danoceras scandinavicum Strand, 1934 is known from Norway, the Siljan District, and a very similar, probably conspecific form, Diestoceras? piersalense Teichert, 1930, occurs in the Pirgu of Estonia (Strand 1934; Frey 1987). The apical fragments of Transorthoceras osmundsbergense n. sp. and Orthoceratidae gen. et. sp. indet. B (Kröger 2007, figs 4h, 5c) from the slightly older faunas of the Siuge Member of the Ärina Formation (Hirnantian Stage; Porkuni Regional Stage; Normalograptus extraordinarius graptolite Zone) are very similar, and likely to be conspecific. The annulated orthocerid Striatocycloceras foerstei (Teichert, 1930) is known from the latest Ordovician of Estonia (Kröger \& Isakar 2006). Probably some of the proteocerids occur also in Estonia and in the older Boda Limestone of the Siljan District, but descriptions of the rich and abundant cephalopod faunas are still needed for detailed comparisons.

Isorthoceras junceum (Hall, 1847), of the Glisstjärn Formation is known from North America, and S.foersteri was described from Siberia (Balashov 1962). There is no further agreement or faunal overlap at species level with the Hirnantian and Ashgillian cephalopod faunas of Laurentia (Anticosti Island, Canada; Holland \& Copper 2008; Gaspé Peninsula, Canada, and central North America; Flower 1946; Foerste 1936), Ireland, Wales, and Cumbria (Evans 1993, 2002); the Prague Basin, Czech Republic (Marek 1999), and elsewhere.

The comparison shows that the cephalopod association of the Glisstjärn Formation agrees with other Late Ordovician faunas known from Baltoscandia. However, there is usually a poor agreement with non-Baltic associations such as those from Laurentia, Avalonia, and the agreement of the Perunica association is notably poor.

\section{Composition of the fauna and palaeoecological interpretation}

The Glisstjärn Formation is a cephalopod limestone strongly dominated by proteocerids: more than $90 \%$ of the specimens belong to T. osmundsbergense and Isorthoceras dalecarlense. A detailed analysis of relative abundances is difficult because the two dominant species/genera are not easy to distinguish in the field. Our collecting yielded an approximate ratio of 2/1 of $T$. osmundsbergense (34 specimens) against Isorthoceras dalecarlense n.sp. (16 specimens). Apart from these dominant, simple orthocones our collecting concentrated on the determination of the taxonomic richness of the fauna. Therefore rare taxa, such as Retizitteloceras rarum and Danoceras scandinavicum, are strongly over-represented in our collection, as they are known only from single specimens among thousands of proteocerids. A reliable determination of the evenness (e.g. Pielou's evenness) is therefore impossible based on our data. For instance, Figure $2 \mathrm{~F}$ gives an impression of the strong dominance of proteocerids, which indicates a very low evenness of the cephalopod fauna. Such a concentration of orthocones is known, but yet undescribed, from other Late Ordovician shallow water cephalopod occurrence such as from the late Katian Keisley Limestone and the Troutbeck Formation in Northern England (pers. comm. David Evans). Remarkable is also the absence of endoceridans and actinoceridans in the Glisstjärn Formation (Fig. 3). This is similar to the shallow peri-reefal setting of the Siuge Member, Porkuni Regional Stage, Estonia (Kröger 2007). In contrast, however, in Porkuni oncoceridans are more diverse (6 species) and most abundant (45\%, $n=27$ specimens) (orthocerids, $32 \%, n=19$ specimens; 9 ascocerids, $15 \%, n=9$ specimens; discocerids, $8 \%, n=5$ specimens). The Pielou's evenness of the Porkuni association is high (0.863). The Siuge Member and the Glisstjärn Formation represent shallow water peri-reefal environments, a depositional setting that is generally not much different from the late Katian Saluda Formation in central USA (see e.g. Hatfield 1968) which represents a very different taxonomic composition with oncocerids dominating the diversity (Fig. 3). Because in all known Hirnantian deposits endoceridans, and actinoceridans are very rare or absent the faunal change is interpreted as reflecting specific Hirnantian climatic conditions leading to the post-Or-

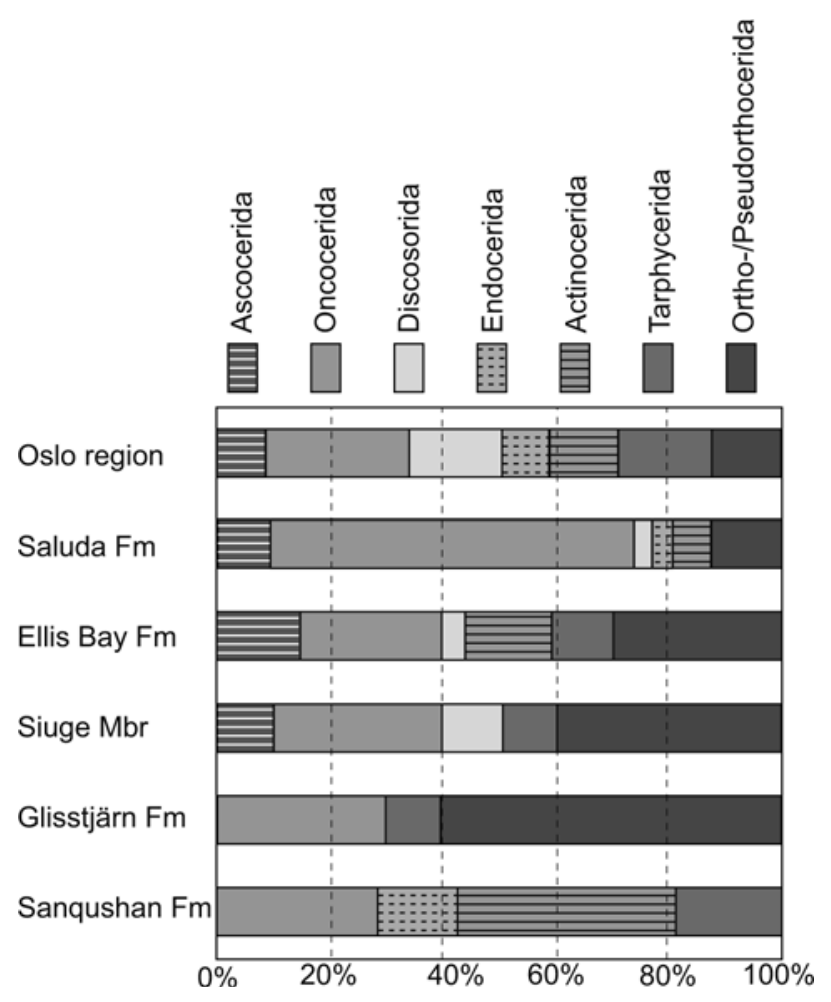

Figure 3. Diagrammatic representation of the relative species diversity of the occurring cephalopod orders of well studied Late Ordovician units (see Table 1 for detailed data). Note the lack of actinocerids and endocerids in the Glisstjärn Formation, also note the similarity with the Siuge Member, Porkuni Regional Stage, Estonia. 
dovician decline of these groups (see also Kröger et al. 2009).

Relative abundances of cephalopods of other Late Ordovician occurrences are poorly studied. Orthocones appear to be the dominant group in many collections, with actinoceridans being an important component. Comparisons of the relative diversities of cephalopods from six different Late Ordovician associations emphasize the distinctiveness of the Glisstjärn association (Fig. 3), with its reduced diversity at higher taxonomic levels.

The taphonomic features visible on the cephalopod conchs indicate that the Glisstjärn Formation does not represent an event bed, but rather a concentration of beached conchs. Many cephalopod conchs show signs of reworking, bioerosion (Fig. 4B), as well as fragmentation. Telescoping is rare, and preserved apices are also very rare. However, with the exception of small pits in one specimen Danoceras scandinavicum (PMU 25194, Fig. 4B), epizoans are not found on the cephalopod conchs. Long drifting times and a distant origin of the orthoconic conchs can be excluded by the sheer number of conchs and by the poor sorting of conch size classes. The wide spectrum of conch sizes also speaks against the concentrations deriving from a spawning place. Thus, the given evidence is indicative for time averaging in a relatively high energetic environment, probably representing a time when conchs from cephalopods were beached that lived more offshore.

It is highly probable that the cephalopod association of the Glisstjärn Formation represents the remains of a fauna that lived in the open water, in somewhat deeper
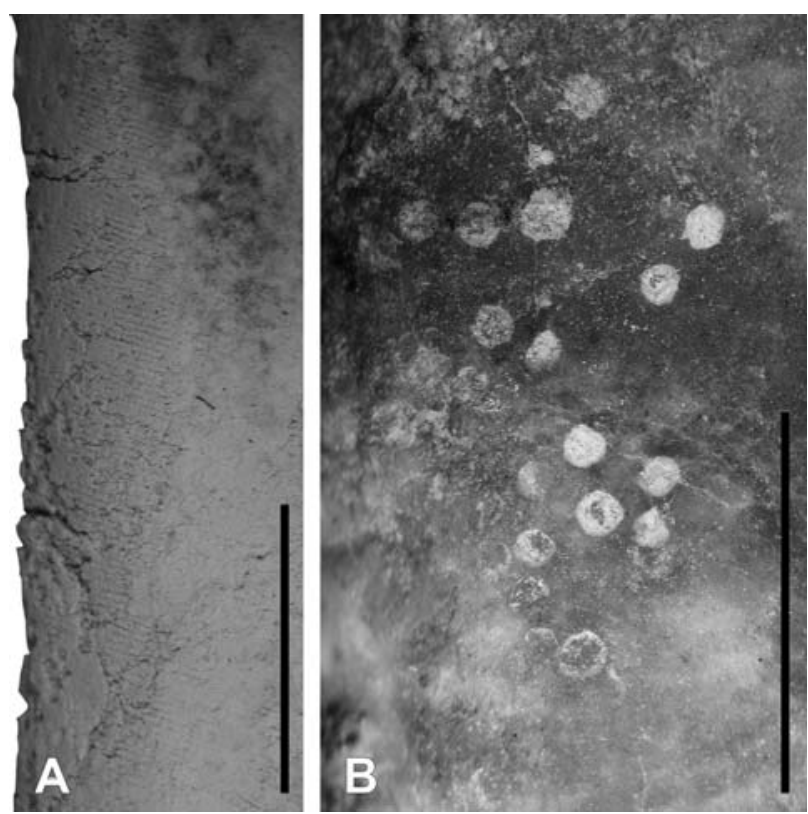

Figure 4. Details of the conch surface of cephalopods from the nautiloid bed at the top of Glisstjärn Formation, Hirnantian, Late Ordovician, Osmundsberget quarry, Rättvik Municipality, Siljan District, Sweden. A. Isorthoceras? junceum (Hall, 1847), PMU 25225; B. Danoceras scandinavicum Strand, 1934, PMU 25194, shallow, irregularly spaced circular pits. Scale bar $5 \mathrm{~mm}$. environments near the place of deposition. Kröger et al. (2009) demonstrated that orthoceridan conchs are often concentrated in black shales and sediments of deep depositional environments, resulting from death assemblages derived from schools of cephalopods living in the free water column. Similarily, the mass occurrence of orthocerids in the Glisstjärn Formation, may therefore indicate conditions in the open water that fostered cephalopod population growth. A plausible cause may be eutrophication of the waters in the area.

\section{Systematic palaeontology}

\section{Terminology}

The coiled nautiloid specimens are described using two parameters deployed for the description of ammonoids by Korn \& Klug (2003). The whorl expansion rate is calculated as WER $=(\mathrm{dml} / \mathrm{dms})^{2}$ where $\mathrm{dml}$ is the diameter of the conch and $\mathrm{dms}$ the diameter $360^{\circ}$ before $\mathrm{dml}$. The whorl width index (WWI) is the whorl width divided by the whorl height.

Order Oncocerida Flower in Flower \& Kummel, 1950 Family Oncoceratidae Hyatt, 1884

\section{Beloitoceras Foerste, 1924}

Type species. Oncoceras pandion Hall, 1861, Black River Formation, Beloit, Wisconsin, USA; by original designation.

Diagnosis. Strongly curved, relatively slender brevicones with ovate, compressed cross section. Conch smooth or with fine transverse ornament. Maximum conch diameter situated within adapical one-half to one third of body chamber. Antisiphuncular outline of conch concave over entire length, prosiphuncular outline broadly convex. Five to eight chambers per distance similar to corresponding conch cross section. Body chamber short with well developed hyponomic sinus at convex side. Siphuncle slender, situated close to convex margin of conch curvature, with subtubular segments. Septal necks short suborthochoanitic to cyrtochoanitic. Connecting rings thin, homogenous (compiled from Sweet 1964a; Frey 1995).

Stratigraphic and geographic range. Middle-Late Ordovician North America, Baltoscandia, North and South China.

\section{Beloitoceras heterocurvatum Strand, 1934}

Figures 5A, B

1934 Beloitoceras heterocurvatum Strand: 76, pl. 10, figs 8-10p. 1987 Beloitoceras heterocurvatum. - Frye: 84, figs 3A-D. [cum syn.] Material. Two specimens, PMU 25195, 25196 from the nautiloid bed at the top of the Glisstjärn Formation, Hirnantian, Late Ordovician, Osmundsberget, Rättvik Municipality, Siljan District, Sweden (locality Osmundsberget 1 of Ebbestad \& Högström 2007b).

Diagnosis. Beloitoceras with strongly compressed cross section (ratio conch width/height $0.75-0.8$ ) with conch margins at concave and convex side of conch curvature. Depth of body chamber somewhat less than maximum conch height. Body chamber with varying curvature, in some specimens endogatrically curved. About 6 chambers si- 


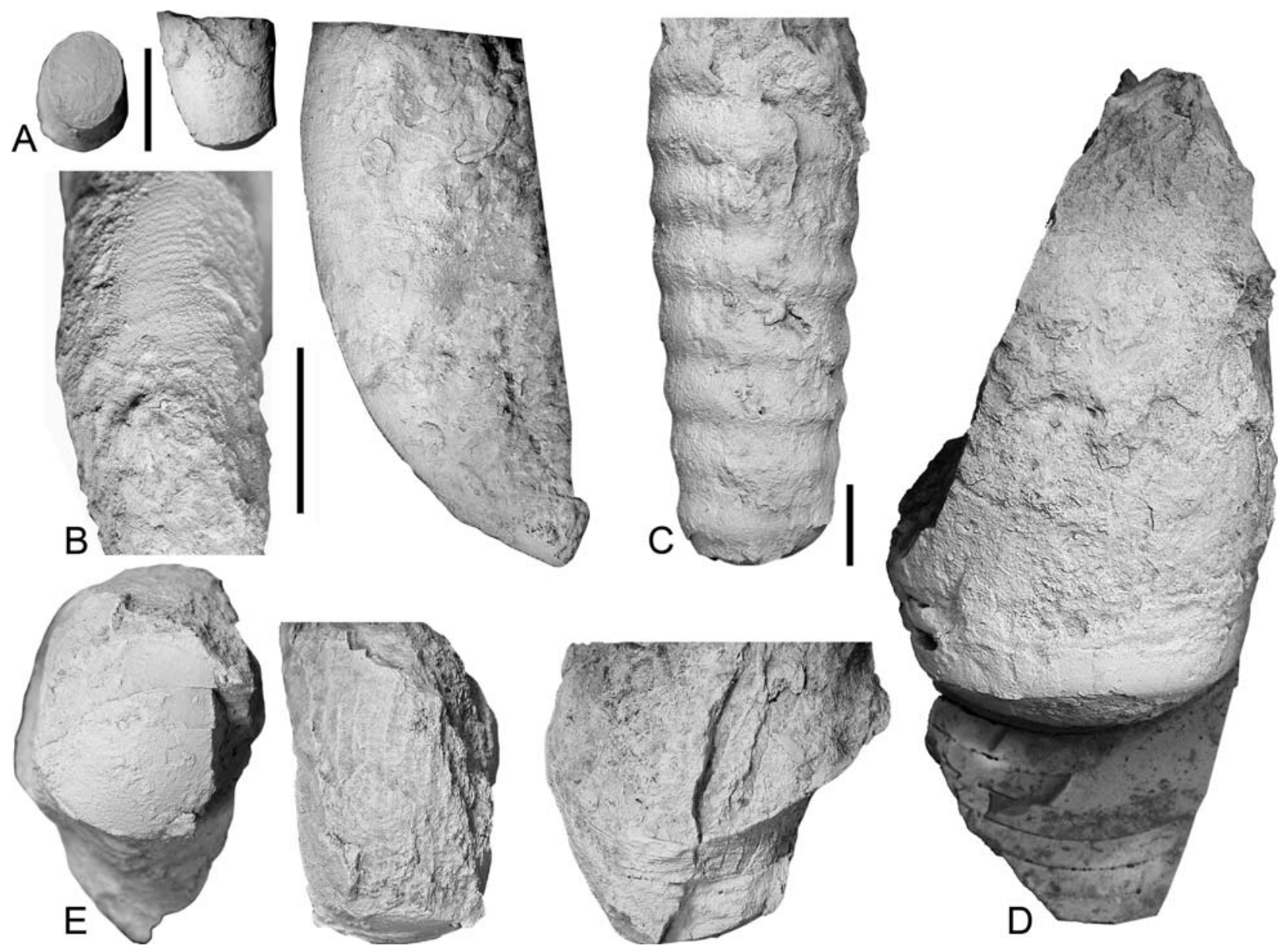

Figure 5. Rare cephalopods from the nautiloid bed at the top of Glisstjärn Formation, Hirnantian, Late Ordovician, Osmundsberget quarry, Rättvik Municipality, Siljan District, Sweden. A-B. Beloitoceras heterocurvatum Strand, 1934; A. PMU 25195, adapical and lateral view; B. PMU 25196, Adapical view with detail of ornamentation and lateral view; C. Striatocycloceras cf. foerstei (Teichert, 1930), PMU 25204, lateral view; D. Danoceras scandinavicum Strand, 1934, PMU 25194; E. Retizitteloceras rarum n. sp., PMU 25197, holotype, adapical view, view at convex side of conch curvature, prosiphuncular side, note the reticulate ornamentation, and lateral view. Scale bar $10 \mathrm{~mm}$. Same scale in all figures as in A, except B, adapical view, C.

milar to the height of the conch cross section. Sutures with deep lateral lobes. Siphuncle situated near ventral margin, segments c. twice as high as wide with slightly convex vertical outline (compiled from Strand 1934).

Description. Specimen PMU 25196 is fragment of phragmocone with a diameter of 7-22 $\mathrm{mm}$, and length $\mathrm{c}$. $52 \mathrm{~mm}$ (angle of expansion c. $16^{\circ}$ ). Conch cross section elliptically compressed with angular, or keeled margin at convex side of conch curvature. Conch surface transversally ornamented with fine striae, about 2 per one millimetre at conch cross section $12 \mathrm{~mm}$. Striae form pronounced V-shaped sinus at convex side of conch curvature. Chamber height $2.5 \mathrm{~mm}$ at cross section height $11 \mathrm{~mm}$ ( 0.23 of corresponding conch height). Sutures directly transverse or with very shallow lateral lobe only. Siphuncle submarginal with diameter of septal perforation $0.7 \mathrm{~mm}$ at apical end of specimen ( 0.1 of conch height).

Specimen PMU 25195 is fragment of phragmocone with diameter 9-12 $\mathrm{mm}$, and length $14 \mathrm{~mm}$ (angle of expansion $12 \mathrm{~mm}$ ). At conch height $12 \mathrm{~mm}$, width $9 \mathrm{~mm}$ (ratio conch width/height 0.77 ). Cross section el- liptical with angular, or keeled margins. Chamber height $2.3 \mathrm{~mm}$ at conch height $11 \mathrm{~mm}(0.21$ of corresponding conch height). Sutures form shallow lateral sinus. Conch ornamented with fine transverse striae. Siphuncular perforation with distance of $0.8 \mathrm{~mm}$ from conch margin at convex side of conch curvature with diameter $0.7 \mathrm{~mm}$.

Stratigraphic and geographic range. Pirgu Regional Stage (latest Katian), "Sadewitzer Kalk" from erratics, Northern Poland (Roemer 1861), and Estonia (Strand 1934); from Sørbakken and Bønsnes formations (latest Katian, Rawtheyan equivalent), Norway; from Boda Limestone (latest Katian), and Glisstjärn Formation (Hirnantian), Siljan District, Sweden.

Remarks. The specimens, described above, agree in conch shape, ornamentation and position and dimension of the siphuncle with B. heterocurvatum described from Norway, Estonia, and the Boda Limestone of the Siljan District, Sweden. Most characteristic is the keeled conch margin. Strand (1934) described some endogastrically curved specimens under B. heterocurvatum, 
which probably belong to Strandoceras tyriense (Strand, 1934) a discosorid with a similar keeled conch cross section.

\section{Retizitteloceras n. gen.}

Etymology. From the Latin rete, lattice, refers to the characteristic ornamention of this genus which is otherwise similar to Zitteloceras Hyatt, 1884.

Type species. Retizitteloceras rarum $\mathrm{n}$. sp.

Diagnosis. Strongly curved brevicone with angle of expansion of $30^{\circ}$ or more and with compressed to circular conch cross section. Ornamented with transverse and longitudinal lirae. About 40 lirae around circumference. Distance of transverse lirae about 7 per $5 \mathrm{~mm}$. Transverse ornament less well developed than longitudinal. Septal spacing narrow with about 12 chambers per distance similar to corresponding conch height. Siphuncle marginal at convex side of conch curvature with diameter 0.19 of corresponding conch height.

Stratigraphic and geographic range. Known from type horizon and locality only.

Remarks. The new genus is transitional between the Silurian Clathroceras Foerste, 1926 and Zitteloceras Hyatt, 1884. The ornamentation is similar to the former and the general conch form agrees with Zitteloceras. Clathroceras differs in having a nearly straight conch, Zitteloceras in lacking longitudinal lirae. The genus is assigned to the Onceratidae provisionally, because the adult peristome is unknown and the conch shape is in the general very similar to Zitteloceras.

\section{Retizitteloceras rarum n. sp.}

Figure 5E

Etymology. From the Latin rarus, referring to the rarity of this species. Holotype. PMU 25197.

Type locality. Osmundsberget quarry, Rättvik Municipality, Siljan District, Sweden (locality Osmundsberget 1 of Ebbestad \& Högström 2007b).

Type horizon. Nautiloid bed, top Glisstjärn Formation, Hirnantian, Late Ordovician.

Material. Holotype only.

Diagnosis. Same as for genus because of monotypy.

Description. Holotype PMU 25197 fragment of phragmocone and body chamber with conch height 15$28 \mathrm{~mm}$. Conch cross section circular or slightly compressed. Position of last chamber of phragmocone at conch height $24 \mathrm{~mm}$. Angle of expansion of phragmocone approximately $30^{\circ}$. Ornamented with reticulate pattern of transverse and longitudinal lirae. Transverse lirae slightly less well developed and subordinate to longitudinal lirae. About 40 longitudinal lirae around circumference. About 7 transverse lirae at $5 \mathrm{~mm}$ at conch height $22 \mathrm{~mm}$. Chamber height $2 \mathrm{~mm}$ at conch height $19 \mathrm{~mm}$. Sutures directly transverse. No septal crowding. Siphuncle marginal at convex side of conch curvature with diameter of septal perforation $2.8 \mathrm{~mm}$ at conch height $15 \mathrm{~mm}$.

\section{Family Diestoceratidae Foerste, 1926}

\section{Danoceras Troedsson, 1926}

Type species. Danoceras ravni Troedsson, 1926, Late Ordovician Cape Calhoun series, northern Greenland; by original designation.

Diagnosis. Straight, or faintly curved brevicones with slightly contracted aperture. Siphuncle marginal or nearly so. Septal necks cyrtochoanitic. Siphuncular segments elongate, subtrapezoidal. Irregular annulosiphuncular deposits (compiled from Sweet 1964a).

Stratigraphic and geographic range. Late Ordovician North America, Baltoscandia, Siberia.

\section{Danoceras scandinavicum Strand, 1934}

Figures 4B, 5D, 6H

1934 Danoceras scandinavicum Strand: 82, pl. 11, figs 9a, 9b, 10. 1987 Danoceras scandinavicum. - Frye: 94, fig. 3 i.

Material. One specimen, PMU 25194 from the nautiloid bed at top of Glisstjärn Formation, Hirnantian, Late Ordovician, Osmundsberget quarry, Rättvik Municipality, Siljan District, Sweden (locality Osmundsberget 1 of Ebbestad \& Högström 2007b).

Diagnosis. Straight Danoceras with dorso-lateral convex outlines. Ornamented with faint distant striae in juvenile growth stages. Maximum conch diameter at base of living chamber. Cross section compressed with ratio conch width/height $0.8-0.9$. Sutures with shallow lateral lobe (compiled from Strand 1934).

Description. Specimen PMU 25194 is a fragment of phragmocone and body chamber with ratio conch width/height 0.8 at base of body chamber. Diameter at position of last septum $32 \mathrm{~mm}$. Part of phragmocone with diameter $24-30 \mathrm{~mm}$, and length $20 \mathrm{~mm}$ (apical angle $17^{\circ}$ ). Preserved part of body chamber with length of $32 \mathrm{~mm}$. Sutures with distance of $4 \mathrm{~mm}$ at conch height $32 \mathrm{~mm}$ ( 0.125 of conch height), nearly transverse. Conch surface not preserved, but adoral parts of body chamber apparently smooth. Siphuncle marginal with diameter of septal perforation $1.7 \mathrm{~mm}$, and maximum expansion of connecting ring between septa $3 \mathrm{~mm}$ at conch height $32 \mathrm{~mm}$.

Stratigraphic and geographic range. Husebergøya Formation (latest Katian, Rawtheyan equivalent), Norway; from Boda Limestone (latest Katian), and Glisstjärn Formation (Hirnantian), Siljan District, Sweden.

Remarks. As the outer conch is poorly preserved, this specimen is only tentatively assigned to $D$. scandinavicum, but it generally agrees with this species in conch form and position of the siphuncle.

Order Orthocerida Kuhn, 1940

Family Dawsonoceratidae Flower, 1962

\section{Dawsonoceras Hyatt, 1884}

Type species. Orthoceras annulatum Sowerby, 1816 by original designation.

Diagnosis. Slender, circular or slightly compressed orthocones with symmetrically curved septa and straight transverse sutures. Sutures 
parallel to annulations in each groove of the annulations. Annulations regularly spaced, with fine transverse ornament, or growth lines. Growth lines in some species festooned. In some species longitudinal ridges may form nodes at the ridges of the annulations. Siphuncle subcentral in early growth stages, central in late growth stages, narrow, but expanded within chambers. Septal necks short suborthochoanitic to achoanitic, in advanced forms short reticulate. Incipient annulosiphuncular deposits, and mural cameral deposits are known (after Kröger \& Isakar 2006)

Stratigraphic and geographic range. Late Ordovician (Vormsi Regional Stage) to Late Silurian; worldwide.

Remarks. The genus was extensively discussed in Kröger \& Isakar (2006: 153, 156).

\section{Dawsonoceras gregarium n. sp.}

Figures $6 \mathrm{~B}, \mathrm{C}, 7 \mathrm{~B}, 8$

Etymology. The name from Latin gregarious, pertaining to the gregarious occurrence of the taxon.

Holotype. PMU 25198.

Type locality. Osmundsberget quarry, Rättvik Municipality, Siljan District, Sweden (locality Osmundsberget 1 of Ebbestad \& Högström 2007b).

Type horizon. Nautiloid bed, top Glisstjärn Formation, Hirnantian, Late Ordovician.

Material. Five additional specimens, PMU 25199-25202, from type locality and horizon; PMU 25203, from the Hindella coquina in unit B of the Upper Boda Member at Osmundsberget 5, Osmundsberget quarry, Rättvik Municipality, Siljan District, Sweden.

Diagnosis. Annulated orthoconic or faintly curved longicones with circular cross section. Angle of expansion c. $5^{\circ}$ in adolescence, subcylindrical in later growth stages. Ornamented with reticulate pattern of faint raised lirae. Annulation and longitudinal lirae more narrowly spaced than in D. fenestratum (Eichwald, 1860). About 10 ribs at length equivalent to conch diameter and 15 transverse lirae between two consecutive ribs. Chamber height c. 0.3 of corresponding diameter. Siphuncle subcentral with diameter of septal perforation 0.8 of diameter conch. Septal necks achoantic to very short loxochoanitic. No cameral or endosiphuncular deposits known

Description. Holotype is fragment of phragmocone and part of body chamber with total length of $45 \mathrm{~mm}$, conch cross section 16-19 mm (angle of expansion $3.8^{\circ}$ ). Length of preserved part of body chamber $24 \mathrm{~mm}$. Ornamented with 10 rounded ribs at length equivalent to conch cross section, about 3 ribs occur between two consecutive septa. Ribs form faint lateral sinus, are slightly obliquely transverse, slightly apically directed toward venter. Between two consecutive ribs about 15 faint straight raised lirae, parallel to ribs. Transverse lirae are more pronounced on ribs than in interspaces between ribs. Approximately 70, irregularly spaced raised longitudinal lirae around circumference.
Septal spacing narrow, with 5 chambers at length of $24 \mathrm{~mm}$. Depth of septal curvature $4 \mathrm{~mm}$ at adoralmost chamber. Siphuncle subcentral, center of siphuncle $7 \mathrm{~mm}$ from conch wall at apicalmost septum. Septal necks very short achoanitic-loxochoanitic. Diameter of septal perforation $1.2 \mathrm{~mm}$ at adapicalmost septum. PMU 25199 is $38 \mathrm{~mm}$ long with diameter $11.5-15 \mathrm{~mm}$ (angle of expansion $5.2^{\circ}$ ).

Remarks. D. fenestratum (Eichwald, 1860), which is common in the Porkuni Regional Stage of Estonia (Kröger \& Isakar 2006) differs from the Osmundsberget species in having only five to six annulations per distance similar to the conch cross section and only c. 20 longitudinal lirae across the circumference. The internal characters of the more densely reticulate ornamented Spyroceras perroti (Clarke, 1897) from the Richmondian Maquoketa Formation in Minnesota (Foerste 1932) are not known. But in $S$. perroti only 8 ribs occur at a length equal to conch diameter and the conspicuous longitudinal ribs are about 30 in number.

Family Orthoceratidae McCoy, 1844

\section{Striatocycloceras Kröger \& Isakar, 2006}

Type species. Orthoceras undulostriatum Hall, 1847, Trenton Limestone, Late Ordovician, Middleville, New York, USA; by original designation.

Diagnosis. Slender, circular or slightly compressed orthocones with asymmetrically curved septa and straight transverse or slightly oblique sutures. Sutures parallel, or nearly so, to the annulations. Annulations slightly irregularly spaced, with fine transverse ornament. Siphuncle eccentric, narrow, tubular or slightly expanded within the chambers Septal necks orthochoanitic. Cameral and endosiphuncular deposits not known (from Kröger \& Isakar 2006).

Stratigraphic and geographic range. Middle-Late Ordovician North America, Baltoscandia.

\section{Striatocycloceras cf. foerstei (Teichert, 1930)}

Figures 5C, 6E

1858 Orthoceras arcuolyratum Schmidt: 196 [nom. nud.] 1916 Orthoceras arcuolyratum. - Twenhofel: 298.

1930 Leurocycloceras foerstei Teichert: 278, pl. 6, figs 13-16.

1962 Leurocycloceras foerstei. - Balashov: 110, pl. 48, fig. 3.

2006 Striatocycloceras foerstei. - Kröger \& Isakar: 151, figs 7q, 10h.

Material. Three specimens, PMU 25204-25206 and four unnumbered specimens at collection PMU, from nautiloid bed at top of Glisstjärn Formation, Hirnantian, Late Ordovician, Osmundsberget quarry, Rättvik Municipality, Siljan District, Sweden (locality Osmundsberget 1 of Ebbestad \& Högström 2007b).

Figure 6. Median sections of cephalopods from the nautiloid bed at the top of Glisstjärn Formation, Hirnantian, Late Ordovician, Osmundsberget quarry, Rättvik Municipality, Siljan District, Sweden. A. Transorthoceras osmundsbergense n. sp., PMU 25275, apical part of phragmocone; B-C. Dawsonoceras gregarium n. sp. PMU 25198, holotype; B. Detail of siphuncular tube and septal necks; C. Part of phragmocone; D. Proteoceratidae indet., PMU 25270; E. Striatocycloceras cf. foerstei (Teichert, 1930), PMU 25206; F. Proteoceratidae indet., PMU 25267; G. Transorthoceras osmundsbergense n. sp., PMU 25273, apical part of phragmocone; H. Danoceras scandinavicum Strand, 1934, PMU 25194. Scale bar $10 \mathrm{~mm}$ except in A, B, E $1 \mathrm{~mm}$. 

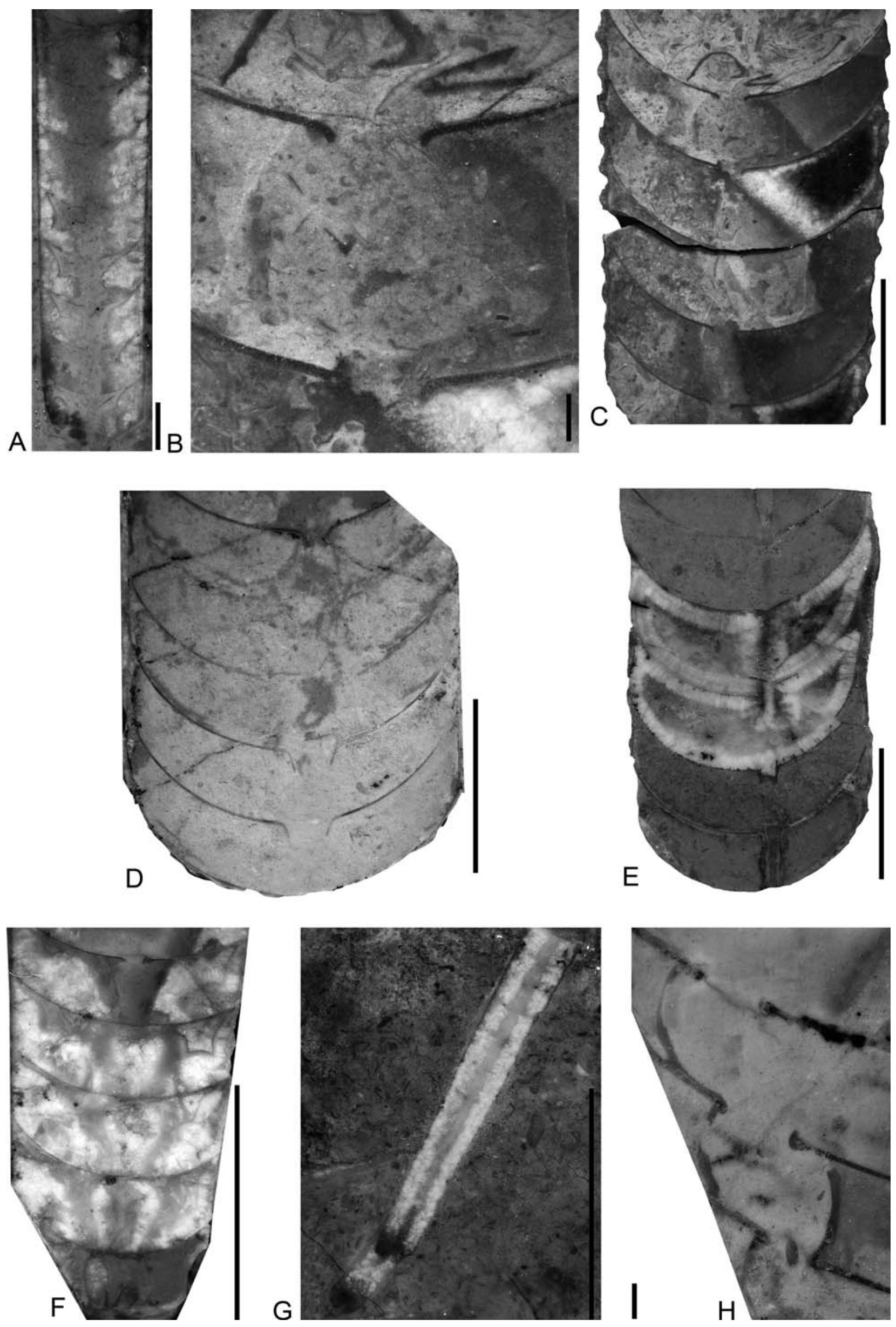
Table 1. Number of species per order in the Glisstjärn Formation, Hirnantian, Siljan District, Sweden; Siuge Member, Hirnantian, Estonia (from Kröger 2007, plus undescribed tarphycerid, in brackets, see text); Saluda Formation, latest Katian, central USA (from Flower 1946; Frey 1995); Ellis Bay Formation, Hirnantian, Anticosti Island, Canada (from Holland \& Copper 2008); Husebergøya, Sørbakken and Bønsnes formations, latest Katian, Norway (from Strand 1934); Sanqushan Formation, South China (from Lai 1980, 1981).

\begin{tabular}{|c|c|c|c|c|c|c|}
\hline Order & $\begin{array}{l}\text { Glisstjärn } \\
\text { Formation }\end{array}$ & Siuge Member & $\begin{array}{l}\text { Saluda } \\
\text { Formation }\end{array}$ & $\begin{array}{l}\text { Ellis Bay } \\
\text { Formation }\end{array}$ & Oslo Region & $\begin{array}{l}\text { Sanqushan } \\
\text { Formation }\end{array}$ \\
\hline Actinocerida & & & 2 & 4 & 4 & 8 \\
\hline Ascocerida & & 1 & 3 & 4 & 3 & \\
\hline Discosorida & & 1 & 1 & 1 & 6 & \\
\hline Endocerida & & & 1 & & 3 & 3 \\
\hline Oncocerida & 3 & 3 & 20 & 7 & 9 & 6 \\
\hline Ortho-Pseudorthocerida & 6 & 4 & 4 & 8 & 4 & \\
\hline Tarphycerida & 1 & (1) & & 3 & 6 & 4 \\
\hline
\end{tabular}

Diagnosis. Straight or very slightly curved Striatocycloceras with circular cross-section and medium apical angle of approximately 8 . Four to six irregularly spaced annulations at a distance that equates the corresponding conch diameter. Acute annulations slightly oblique toward growth direction with slight lateral sinus, with approximately 10 growth lines per annulation. One suture line at every groove of the annulation, sutures and annulations run parallel. Siphuncle central. Short orthochoanitic septal necks.

Description. Specimen PMU 25204 (Fig. 5C) is a fragment of a body chamber with a length of $48 \mathrm{~mm}$ and diameter of $17-23 \mathrm{~mm}$ (angle of expansion $7^{\circ}$ ), with seven transverse annulations (distance between annulations c. 0.2 of distance similar to conch cross section). Amplitude of annulation $1.4 \mathrm{~mm}$ at conch cross section $21 \mathrm{~mm}$. Annulations slightly inclined, sloping in adoral direction at antisiphuncular side of conch. Last septum at conch diameter $17 \mathrm{~mm}$ with depth of septal curvature of c. $4 \mathrm{~mm}$. Cross section circular or slightly compressed.

Specimen PMU 25205 is a fragment of phragmocone with length $26 \mathrm{~mm}$, cross section diameter $16.5-19 \mathrm{~mm}$ (angle of expansion $5.5^{\circ}$ ), six annulations occur at entire length of specimen. Annulation slightly inclined toward adoral end at antisiphuncular side. One cycle of annulation per chamber length with sutures in valleys between ridges of annulation. Sutures slightly inclined parallel to annulation with distance c. 0.23 of conch cross section. Siphuncle tubular with diameter $1.3 \mathrm{~mm}$ at apical end of specimen $(0.097$ of conch cross section), with distance $6 \mathrm{~mm}$ from conch margin $(0.36$ of conch cross section). Septal curvature $7 \mathrm{~mm}$ at adoral end of fragment ( 0.37 of conch cross section). Septal necks orthochoantic with length $1 \mathrm{~mm}$ at chamber depth of $4.3 \mathrm{~mm}$ ( 0.23 of septal distance).

Smallest fragment PMU 25206 (Fig. 6E), body chamber partly preserved, with diameter $4.5-5.1 \mathrm{~mm}$, length $15 \mathrm{~mm}$ (angle of expansion $2.3^{\circ}$ ). Septal distance $1.9 \mathrm{~mm}$ at conch cross section $4.4 \mathrm{~mm}$ (0.43 of conch cross section). One cycle of annulation per chamber length with sutures in valleys between ridges of annulation. Ornamented with fine transverse striae parallel to annulation. Siphuncle subcentral, tubular, with diameter c. 0.1 of conch cross section. Septal necks orthochoanitic. No endosiphuncular or cameral deposits.

Stratigraphic and geographic range. Nabala - Pirgu Regional Stages, Estonia (Kröger \& Isakar 2006); "Ashgill", Nizhnaia Tchunga, Siberian Platform (Balashov 1962), Hirnantian, Siljan District, Sweden.

Remarks. Kröger \& Isakar (2006) stated that in S. foersteri about 7 irregularly spaced annulations occur. However in the type material figured by Teichert (1930) the number of annulations varies between 4-6 in the different fragments. The species is characterized by a relatively large angle of expansion. The material from the Glisstjärn Formation suggests an increasing angle of expansion at cross sections $5-20 \mathrm{~mm}$, and it appears to be generally lower in angle of expansion than that of the type location. However, a comparison with more material is needed to confirm the differences. S. foersteri differs from other species of Striatocycloceras in having a relatively large angle of expansion and an annulation parallel to the sutures.

\section{Family Proteoceratidae Flower, 1962}

Remarks. The Proteoceratidae were assigned to the Pseudorthoceratacaea by Sweet (1964b), and to the Pseudorthocerida by Kröger \& Isakar (2006). The classification within the Pseudorthoceratacaea/Pseudorthocerida was justified by the shape of the septal necks and the characteristic parietal deposits. Here, the Proteoceratidae are assigned to the Orthocerida. This decision is based upon two arguments: (1) No apical parts of Proteoceras Flower, 1955 are known, but known proteoceratid apices, which belong to Isorthoceras Flower, 1962, are small, spherical and without cicatrix (Ruedemann 1912, pl. 8, figs 4-5; Kröger et al. 2009); a feature which is distinctive for the Orthocerida. (2) At the extreme apical part of Transorthoceras the septal necks are very short suborthochoanitic. The general shape of apical parts, including the septal necks are very similar, and probably conspecific with apical fragments from 

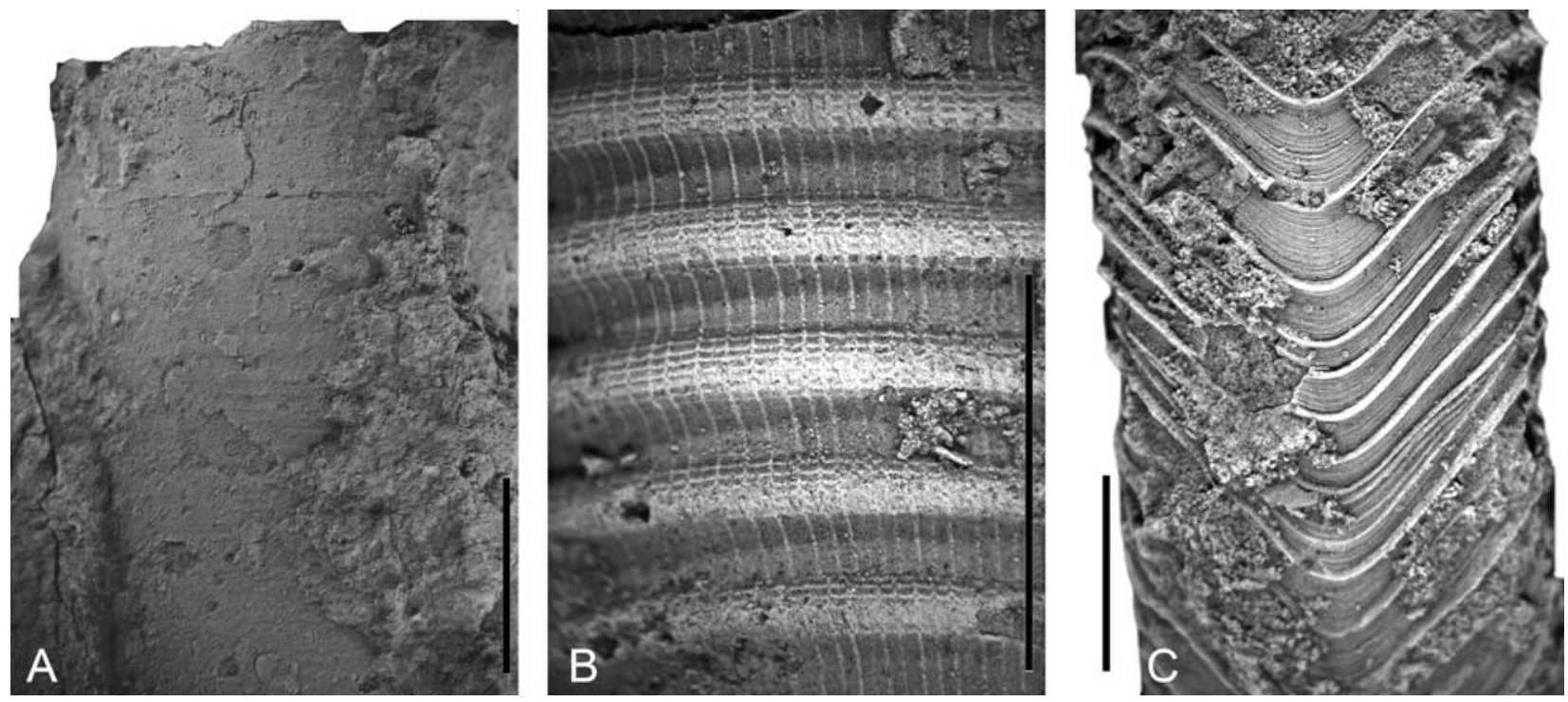

Figure 7. Details of the ornamentation of cephalopods from the nautiloid bed at the top of Glisstjärn Formation, Hirnantian, Late Ordovician and horizon, Osmundsberget quarry, Rättvik Municipality, Siljan District, Sweden. A. Transorthoceras osmundsbergense n. sp. (Barskov, 1980), PMU 25234, note the fine transverse striae; B. Dawsonoceras gregarium n. sp. PMU 25198, holotype; C. Discoceras siljanense n. sp., PMU 25271, ventral view. Scale bars $5 \mathrm{~mm}$.

the Porkuni Stage of Estonia, assigned to Orthoceratidae gen. et. sp. indet. B (Kröger 2007, figs 4h, 5c). The latter has a subspherical initial chamber without cicatrix. It is, therefore, highly probable that the apex of Transorthoceras is similar to the orthocerids from Porkuni.

Moreover, with its ontogenetically changing siphuncle and septal necks, Transorthoceras is transitional between cyrtochoanitic forms, such as Stereoplasmoceras Grabau, 1922, and orthochoanitic forms, such as Pojetoceras Frey, 1995. Both groups, as well as the transitional Transorthoceras have parietal endosiphuncular deposits. Because it is known now that both, suborthochoantiticcyrtochoanitic septal necks, and parietal deposits, which are thought to be distinctive for pseudorthocerids, occur in species with orthocerid, subspherical apices, the suggestion of Kröger \& Isakar (2006) that these characters be used to distinguish between orthocerids and pseudorthocerids must be carefully tested in each specific case. In the case of the proteoceratids it appears now that they must be assigned to the Orthocerida.

\section{Isorthoceras Flower, 1962}

Type species. Orthoceras sociale Hall in Miller, 1877, from the Elgin Member, Maquoketa Formation, latest Katian, Graf, Iowa, USA; by original designation.

Diagnosis. Smooth orthocones with subcircular cross section. Siphuncle subcentral, with barrel-shaped early segments and subcylindrical later segments. Septal necks cyrtochoanitic. Endosiphuncular annuli grow forward and backward, joining those of adjacent segments to form continuous parietal lining of uniform thickness throughout segments (after Flower 1962 and Frey 1995).

Stratigraphic and geographic range. Boda Limestone, late Katian, from Siljan District, Sweden (Niko 2008);
Grange Hill Member, Grange Allen Formation, Longvillan Regional Stage, Sandbian, from County Kildare, Ireland (Evans 2002); Cobourg beds, Ottawa Formation, late Katian, Ottawa, Canada (Wilson 1961); and from the Middle Ordovician (Kirkfieldian Regional Stage) to the Richmondian Regional Stage in eastern and central North America (Frey 1995, 59).

Remarks. Orthoceras bisignatum Barrande, 1877 displays the characteristic siphuncular shape of Isorthoceras, is generally very similar in the general conch shape to other species of Isorthoceras, and must consequently be assigned to this genus. Isorthoceras bisignatum (Barrande, 1877) comb. nov. is known from the Berounian and Kralodvorian Regionnal Stage of the Prague Basin, Czech Republic (Marek 1999). The internal characters of Orthoceras luhai Stumbur, 1956 from the Vormsi Regional Stage of Estonia and the conch surface of Pleurorthoceras subcostatum (Portlock, 1843) from the Killey Bridge Formation, latest Katian of County Tyrone, Ireland, suggests that these species belong to Isorthoceras. However, an unambiguous genus determination is possible only when the conch surface, and the internal characters are better known, respectively.

The small $(<1 \mathrm{~mm})$, spherical apex of Isorthoceras is known from Isorthoceras tenuitextum Hall, 1847, and I. hudsonicum Ruedemann, 1912.

\section{Isorthoceras dalecarlense $\mathbf{n}$. sp.}

Figures 9C, G

Etymology. The name refers to the type region, Siljan District, Dalarna (Latin Dalecarlia), Sweden.

Holotype. PMU 25207. 
Type locality. Osmundsberget quarry, Rättvik Municipality, Siljan District, Sweden (locality Osmundsberget 1 of Ebbestad \& Högström 2007b).

Type horizon. Nautiloid bed, top of Glisstjärn Formation, Hirnantian, Late Ordovician.

Material. Specimens PMU 25208 - 25224 and seven unnumbered specimens from type horizon and locality.

Diagnosis. Smooth, nearly straight Isorthoceras with circular cross section and comparatively low angle of expansion of $6^{\circ}$, chamber distance 0.3 of corresponding cross section, depth of septal curvature c. 0.26 of corresponding cross section. Adult size $>35 \mathrm{~mm}$ in cross section. Siphuncle eccentric in early, subcentral in later growth stages, siphuncular segments slightly expanded within chambers with diameter c. 0.1 of conch cross section. Septal necks short, at tenuous border between cyrtochoanitic to suborthochoanitic. In apical parts of siphuncle thin parietal deposits, that ventrally fuse to irregular endosiphuncular lining at extreme apical part of conch. Cameral deposits not known.

Description. Conch slightly curved with angle of expansion varying between $5.3^{\circ}$ (1st Quantile) $-6.7^{\circ}$ (3rd Quantile), mean 6.1 $(n=11)$. Suture straight and directly transverse with distance between sutures varying from 0.29 of conch diameter (1st Quantile) - 0.35 (3rd Quantile), mean $0.32(n=12)$. Septal curvature between 0.25 (1st Quantile) - 0.28 (3rd Quantile), mean $0.26(n=11)$. Siphuncle slightly eccentric on concave side of conch curvature with distance between 0.39 (1st Quantile) and 0.46 (3rd Quantile), mean 0.42 $(n=10)$ of conch cross section. No migration of the siphuncle is visible at the given material. Siphuncular segments slender barrel shaped with diameter of c. 0.1 of conch cross section.

At apical end of conch thin parietal deposits that fuse to form irregular lining at ventral side of siphuncle.

Holotype is fragment of faintly curved phragmocone with length of $80 \mathrm{~mm}$, and diameter 13-21 mm (angle of expansion $6.4^{\circ}$ ). Conch surface nearly smooth, but details of surface characters not known. Three chambers occur at distance similar to conch cross section at apical end of specimen. Siphuncle slightly eccentric at concave side of conch curvature. Siphuncular segments poorly preserved, but at diameter $18 \mathrm{~mm}$, fragment of barrel shaped segment is preserved with diameter at the septal perforation of $1.2 \mathrm{~mm}$ and maximum diameter of $2.2 \mathrm{~mm}$. Septal necks short cyrtochoanitic to suborthochoanitic, with thin parietal endosiphuncular deposits.

Specimen PMU 25208 is a fragment of a phragmocone with length of $16 \mathrm{~mm}$, and adapical cross section diameter of c. $10 \mathrm{~mm}$. Conch surface is apparently smooth, but details of ornamentation are not visible. Four chambers occur at length of $16 \mathrm{~mm}$ (chamber height is c. 0.4 of correspondent diameter). Septal curvature shallow with depth of c. $2 \mathrm{~mm}$. Siphuncle eccentric with expanded segments, with distance of centre of siphuncle from conch wall $3.2 \mathrm{~mm}$ at apical end of specimen. Diameter of septal perforation c. $0.8 \mathrm{~mm}$, diameter of siphuncle at midlength between chambers c. $1.8 \mathrm{~mm}$. Septal necks short suborthochoanitic. No cameral and endosiphuncular deposits.
Remarks. This is a large species of Isorthoceras. Adult specimens reached a size of more than $35 \mathrm{~mm}$ in cross section. The type and many other species of Isorthoceras attain adult sizes of less than $25 \mathrm{~mm}$ (Foerste 1936; Frey 1995). I. wahlenbergi Niko, 2007 is comparatively large $(31 \mathrm{~mm})$, but little is known about its variation. I. dalecarlense differs from I. wahlenbergi in having a lower angle of expansion (angle of expansion of $I$. wahlenbergi is nearly $9^{\circ}$ against $6^{\circ}$ of I. dalecarlense. Additionally the siphuncular segments of I. dalecarlense seem to be less expanded. The differentiation between Transorthoceras osmundsbergense and I. dalecarlense in fragments with conch cross sections 5$10 \mathrm{~mm}$ is in most cases impossible, because chamber spacing, angle of expansion, shape of the siphuncle, and endosiphuncular deposits are very similar (Figs 10-11). The only difference is the more eccentric position of the siphuncle (eccentricity c. $0.3-0.4$ ). No apical fragments of I. darlecarlense are known. This can be interpreted as reflecting a real rarity of apical parts in the sediments, or as an artefact reflecting the similarity with $T$. osmundsbergense in early growth stages. Therefore, the possibility exists that I.darlecarlense and T. osmundsbergense are sexual dimorphs of the same species.

\section{Isorthoceras? junceum (Hall, 1847)}

Figures 4A, 9H, I

1847 Orthoceras junceum Hall: 204, pl. 47; figs 3a-3f. 1850 Orthoceratites junceum. - Orbigny: 3.

1877 Orthoceras junceum. - Miller: 175.

1886 Orthoceras junceum. - James: 238.

1888 Orthoceras junceum. - Foord: 10.

1897 Orthoceras junceum. - Clarke: 790.

1908 Orthoceras junceum. - Cumings: 1037, pl. 51, fig. 5.

1910 Orthoceras junceum. - Grabau \& Shimer: 48, fig. 1246.

1914 Orthoceras junceum. - Foerste: 144.

1919 Orthoceras junceum. - Bassler: 323, pl. 51, figs 4-7.

1946 Orthoceras junceum. - Flower: 176, 178.

1968 Orthoceras junceum. - Purnell: 104.

1976 Orthoceras? junceum. - Titus \& Cameron: 1216.

1987 "Orthoceras" junceum. - Catalani: 188.

Material. Seven specimens, PMU 25225-25231 from the nautiloid bed, top of Glisstjärn Formation, Hirnantian, Late Ordovician, Osmundsberget quarry, Rättvik Municipality, Siljan District, Sweden (locality Osmundsberget 1 of Ebbestad \& Högström 2007b).

Diagnosis. Transversally ornamented, straight Isorthoceras with circular cross section and comparatively low angle of expansion of $5^{\circ}$, chamber distance $0.2-0.3$ of corresponding cross section. Adult size c. 10-11 mm in cross section. Siphuncle subcentral-central with diameter c. 0.1 of conch cross section (compiled from Hall 1847).

Description. Specimen PMU 25225 (Fig. 4A) is a fragment of a phragmocone and body chamber with total length $42 \mathrm{~mm}$. Body chamber nearly complete with length $28 \mathrm{~mm}$ and maximum conch cross section approximately $10.5 \mathrm{~mm}$. Last septum at diameter $9 \mathrm{~mm}$, last septa crowded. Angle of expansion of entire fragment c. $6^{\circ}$. Height of apical most chamber 1.8 at conch cross section $8.5 \mathrm{~mm}$ ( 0.21 of conch cross section). 
Conch surface ornamented with fine transverse rounded ridges, about 10 per $\mathrm{mm}$. Septal perforation central. No cameral and endosiphuncular deposits.

Specimen PMU 25227 (Figs 9H, I) is a fragment of a phragmocone and body chamber with total length $51 \mathrm{~mm}$, maximum diameter $9.5 \mathrm{~mm}$, and angle of expansion $3.8^{\circ}$. Length of preserved part of body chamber $24 \mathrm{~mm}$. Last septum at $8 \mathrm{~mm}$, no septal crowding. Septal spacing relatively wide with distance $0.3-0.4$ of conch cross section. Siphuncle central, with slightly convex segments. Septal necks suborthochoantic with length c. 0.1 of chamber height. No cameral and endosiphuncular deposits.

Stratigraphic and geographic range. Trenton Limestone, late Katian, from New York, USA (Hall 1847); Rocklandian-Edenian, late Katian, from north central USA (Catalani 1987); Martinsburg Shale, late Katian (Bassler 1919); Utica Shale, late Katian (Flower 1946); Glisstjärn Formation, Hirnantian, Siljan District, Sweden.

Remarks. The shape of the connecting ring and of the septal necks of the types of O.junceum were not described and figured by Hall (1847), but the general conch shape, ornamentation, the position and diameter of the siphuncle, and the comparatively narrow septal spacing clearly indicates that this species must be assigned to Isorthoceras. The species is common, widespread, and characteristic for the late Katian of Laurentia. The specimens from the Glisstjärn Formation, described above, closely agree in conch shape, dimension, and ornamentation with the specimens figured by Hall. Their internal characters are characteristic for Isorthoceras. Because the internal characters of O.junceum are not completely known the specimens from the Glisstjärn Formation are tentatively assigned to I.junceum. The occurrence in the Glisstjärn Formation considerably widens the geographic and stratigraphic range of I.junceum. But probably the species occurs also in the Fjäcka Shale, late Katian, Siljan District (personal observation by BK of material at the PMU 2009).

I. junceum is very similar to O.elongatocinctum Portlock, 1843, which is common in the late Katian of northern Ireland (Evans 1993, 2002). The specimens of 'O.' elongatocinctum, described by Evans (1993) are very similar to I. junceum in general conch shape and dimensions, but differ in having a sculpture that consists of imbricated lamellae instead of raised rounded lirae. The illustration of the internal characters (Evans 1993; Fig. 8) indicates that the species is closely related and should be assigned to Isorthoceras as new combination Isorthoceras elongatocinctum. Orthoceras gratiosum Barrande, 1867 from the Ashgill of the Prague Basin (Marek 1999) is very similar to O. elongatocinctum Portlock, 1843 in general conch shape, ornamentation and siphuncular position, and is probably conspecific with the latter. But details of the internal characters are not known.

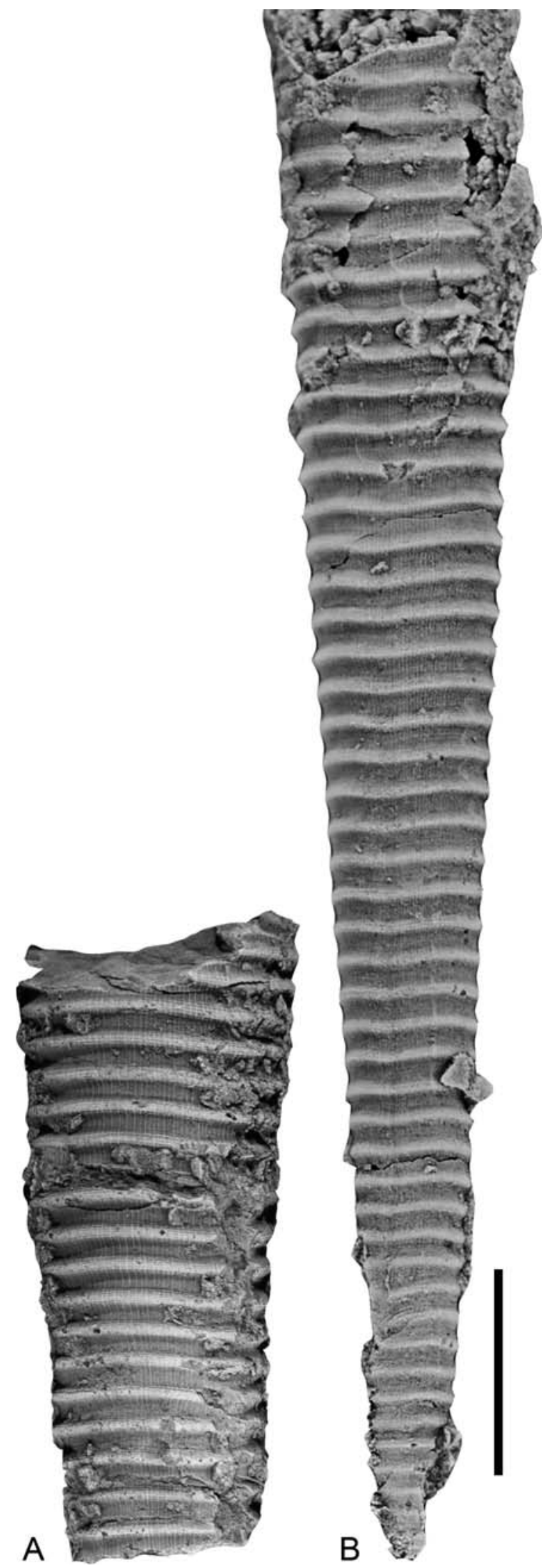

Figure 8. Dawsonoceras gregarium n. sp. Late Ordovician, Osmundsberget quarry, Rättvik Municipality, Siljan District, Sweden. A. PMU 25198, holotype, from the nautiloid bed at the top of Glisstjärn Formation, Hirnantian; B. PMU 25203, juvenile specimen, from the Hindella coquina of unit $\mathrm{B}$ of the Upper Boda Member at locality Osmundsberget 5, Osmundsberget quarry, Siljan District, Sweden. Scale bar $10 \mathrm{~mm}$. 
Other exclusively transversally ornamented Isorthoceras, such as I. tenuistriatum (= Orthoceras strigatum Hall, 1847 fide Ruedemann, 1926), and I. lineolatum Hall, 1847 also reach significantly larger adult sizes.

\section{Transorthoceras n. gen.}

Etymology. From the Latin preposition trans-, beyond, refers to the general similarity of this form with the older Orthoceras Brugiere, 1789. The gender is neuter.

Type species. Transorthoceras osmundsbergense n. sp., Glisstjärn Formation, Hirnantian, Late Ordovician from Osmundsberget quarry, Siljan District, Sweden, by monotypy.

Diagnosis. Orthoconic longicones with apical angle of less than $5^{\circ}$ in late growth stages, nearly smooth conch and central or subcentral, thin, essentially tubular siphuncle. Smooth or ornamented with fine, transverse growth lines. Septal necks short orthochoanitic in adult growth stages. In earlier growth stages siphuncular tube slightly constricted at position of septal perforation and septal necks suborthochoanitic. Siphuncular deposits initially parietal, consisting of thin ventral annuli that grow primarily forward and fuse ventrally to form endosiphuncular lining. Cameral deposits initially episeptal, becoming mural and episeptal during ontogeny.

Remarks. The erection of a new genus is necessary because it differs considerably from other simple longiconic orthoceratids such as Michelinoceras, Orthoceras, Pleurorthoceras, or Pojetoceras. Transorthoceras differs from these genera in having ontogenetically changing septal necks, which are suborthochoanitic in early stages and orthochoanitic in late stages. Similarly the form of the siphuncular segments changes from slightly expanded to strictly tubular. This ontogenetically changing shape of siphuncle and septal necks is a distinctive character of the Proteoceratidae. In fact, the new genus is similar to proteoceratids known from the Middle and Late Ordovician of China (Gangshanoceras Zou, 1988; Pseudoliulinoceras Chen, 1984) in having suborthochoanitic to orthochoanitic septal necks, but both genera differ in having a clearly narrower septal spacing (more than five chambers per diameter similar to conch cross section) and a wider siphuncle. Transorthoceras differs from Eridites Zhuravleva, 1961, in having orthochoanitic septal necks in later growth stages. The siphuncular deposits are similar as in Pojetoceras and proteocerids.

Stratigraphic and geographic range. Known from type horizon and locality only.

\section{Transorthoceras osmundsbergense n. sp.}

Figures 9A, B, D-F

Etymology. The name refers to the type locality.

Holotype. PMU 25232.

Type locality. Osmundsberget, Rättvik Municipality, Siljan District, Sweden (locality Osmundsberget 1 of Ebbestad \& Högström 2007b).

Type horizon. Nautiloid bed, top of Glisstjärn Formation, Hirnantian, Late Ordovician.
Material. Specimens PMU 25233-25265, from nautiloid bed at top of Glisstjärn Formation, Hirnantian, Late Ordovician and horizon, Osmundsberget quarry, Rättvik Municipality, Siljan District, Sweden (locality Osmundsberget 1 of Ebbestad \& Högström 2007b).

Diagnosis. Same as for genus, by monotypy.

Description. Conch circular, with very low angle of expansion, nearly tubular in adult growth stages, with maximum of expansion rate at conch cross section diameter between 5-10 $\mathrm{mm}$ with about 5.25, in earlier and later growth stages angle of expansion $<3.25$. Apicalmost preserved parts with low angle of expansion (c. 2.525 and conch cross section diameter of $<1.4 \mathrm{~mm}$.

Septal distance varies between 0.42 (1st Quantile) and 0.61 (3rd Quantile), with mean $0.52(n=29)$ of corresponding cross section diameter. No tendency of decreasing or increasing chamber width during growth. Septal curvature relatively deep varying between 0.28 (1rd Quantile) and 0.32 (3rd Quantile), mean 0.31 $(n=25)$ of corresponding cross section. Siphuncle tubular, slightly constricted at position of septal perforations, slightly eccentrically positioned (mean distance from conch wall 0.42 of conch cross section, $n=16$ ).

Septal necks orthochoanitic in later growth stages with conch cross section of significantly $>10 \mathrm{~mm}$, suborthochonatic in smaller fragments. Length of septal necks vary between 0.1 (1st Quantile) - 0.19 (3rd Quantile) with mean $0.14(n=11)$ of chamber length.

Siphuncle with thin parietal deposits, which grow forward from septal necks, and form continuous, irregular lining in more apical parts. Endosiphuncular deposits concentrated on ventral part of siphuncle. Hyposeptal, mural, and episeptal cameral deposits in adapical parts of conch.

Holotype PMU 25232 (Figs 9E-F) is a fragment of the phragmocone with a smooth conch surface, laterally eroded with originally circular cross section with diameter $27-30 \mathrm{~mm}$, nearly tubular at length of $110 \mathrm{~mm}$ (angle of expansion less than $2^{\circ}$ ), with septal distance varying between 11-22 mm. Depth of septal curvature about $11 \mathrm{~mm}$, sutures directly transverse, straight. Centre of siphuncle $13 \mathrm{~mm}$ from conch wall where conch cross section is $28 \mathrm{~mm}$ ( 0.46 of conch cross section). Diameter of septal perforation $3 \mathrm{~mm}$, with length of orthochoanitic septal neck of about $2.5 \mathrm{~mm}$ where conch cross section is $30 \mathrm{~mm}$, and chamber length $21 \mathrm{~mm}$. Siphuncle with thin parietal deposits. Weak episeptal, and hyposeptal deposits at prosiphuncular side. Specimen PMU 25234 is fragment of phragmocone with circular or slightly compressed cross section. Specimen is ornamented with fine, irregularly spaced transverse striae, about 5 per $\mathrm{mm}$.

Specimen PMU 25273, and PMU 25274 are fragments of juvenile growth stages with diameter 2.1$5.4 \mathrm{~mm}$, and $1.8-3.1 \mathrm{~mm}$, and length $48 \mathrm{~mm}, 28 \mathrm{~mm}$, respectively. Apical angle is $3.9^{\circ}, 2.7^{\circ}$, and chamber distance varies between $0.4-0.7$ of corresponding conch cross section. Siphuncle nearly tubular with diameter of about 0.1 of conch cross section, subcentral, 

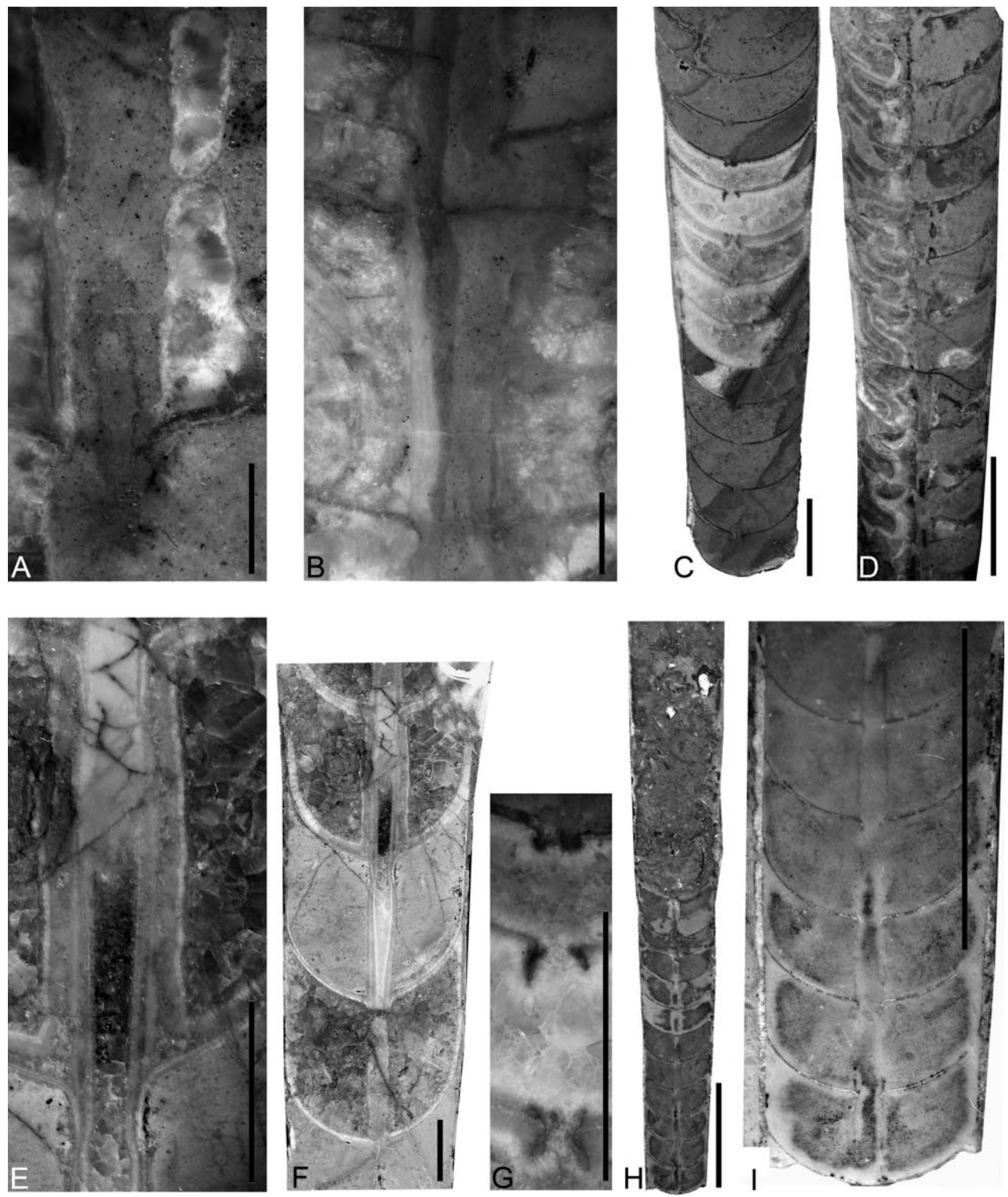

Figure 9. Proteocerids from the nautiloid bed at the top of Glisstjärn Formation, Hirnantian, Late Ordovician, Osmundsberget quarry, Rättvik Municipality, Siljan District, Sweden. A-B. Transorthoceras osmundsbergense n. sp.; A. PMU 25275, early growth stages, detail of siphuncular tube and septal necks, note the irregular parietal deposits; B. PMU 25248, early growth stages, detail of siphuncular tube and septal necks, note irregular parietal deposits and enoisiphuncular lining; C. Isorthoceras dalecarlense n. sp., PMU 25207, holotype, detail of siphuncular tube and septal necks; D-F. Transorthoceras osmundsbergense n. sp.; D. PMU 25275, part of phragmocone; E-F. PMU 25232, holotype, late growth stages; E. Detail of siphuncular tube and septal necks; F. Part of phragmocone; G. Isorthoceras dalecarlense n. sp., PMU 25207, holotype, part of phragmocone; H-I. Isorthoceras? junceum (Hall, 1847), PMU 25227; H. Part of body chamber and phragmocone of nearly adult specimen; I. Detail of Figure 9H. Scale bar $10 \mathrm{~mm}$ except in A-B $1 \mathrm{~mm}$. 
with irregular endosiphuncular lining. Septal necks short suborthochoanitic with length about 0.1 of chamber height.

Remarks. The comparison of Transorthoceras osmundsbergense $\mathrm{n}$. sp. with similar species is difficult because a detailed knowledge of the different growth stages in similar species is necessary. Orthoceras gratiosum Barrande, 1867 from the Ashgill of the Prague Basin, Czech Republic (Marek 1999) is very similar to T. osmundsbergense in general conch shape, siphuncular position and shape. But, because the details of the septal neck are not known an unambiguous generic determination is not possible. Michelinoceras procurrens Barskov, 1980 from the Rodnik Ojsu, Kazakhstan, from the upper Čokparsko horizon (Ojsuj Limestone, uppermost Katian Polyagnathus pacificus condont Zone after Apollonov et al. 1980) is probably conspecific with T. osmundsbergense; the general conch shape, and the known internal characters are identical. However, apical parts of the conch and endosiphuncular deposits are not known from M. procurrens. The Middle Ordovician Michelinoceras chaoi Chang, 1957, is very similar in general conch shape, but differs in having a narrower septal spacing and shorter septal necks. Additionally, the conch surface, and apical characters of M. chaoi are not known, making a direct comparison difficult.

A distinction between T. osmundsbergense and Isorthoceras dalecarlense $\mathrm{n}$. $\mathrm{sp}$. is very difficult in fragments with diameters of 5-10 $\mathrm{mm}$, because the angle of expansion and the shape of the siphuncle of the two species are very similar during this growth stage and the preservation of the material often does not allow for a distinction of details of the septal necks in the smaller specimens (Figs 10, 11). The only difference between the two species in this growth stage is probably the position of the siphuncle, which is less eccentric in Transorthoceras (c. 0.5-0.4).

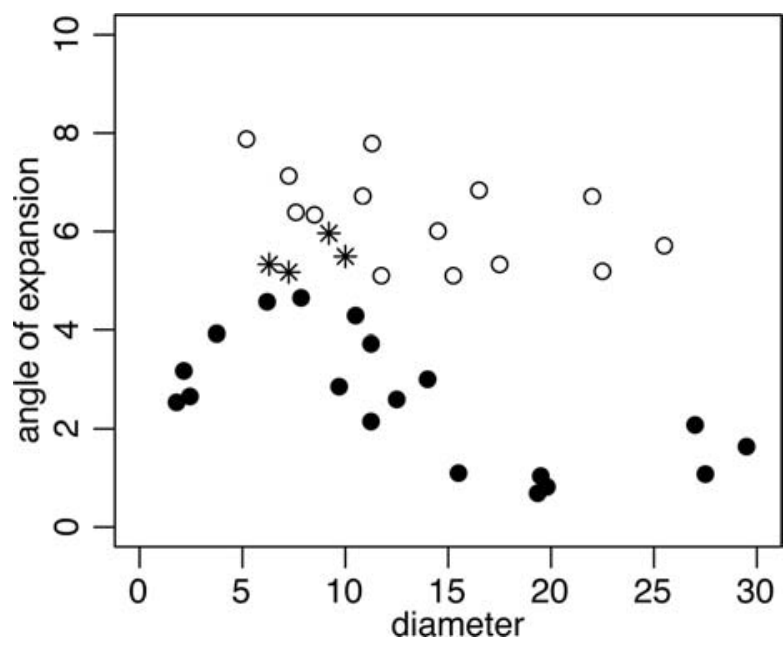

Figure 10. Angle of expansion of specimens of Transorthoceras osmundsbergense n. sp. (black circles) and Isorthoceras dalecarlense $\mathrm{n}$. sp. (white circles). Note the difficulty to distinguish between the two species at fragment diameters 5-10 mm (stars denote indet. fragments with transitional conch morphology).

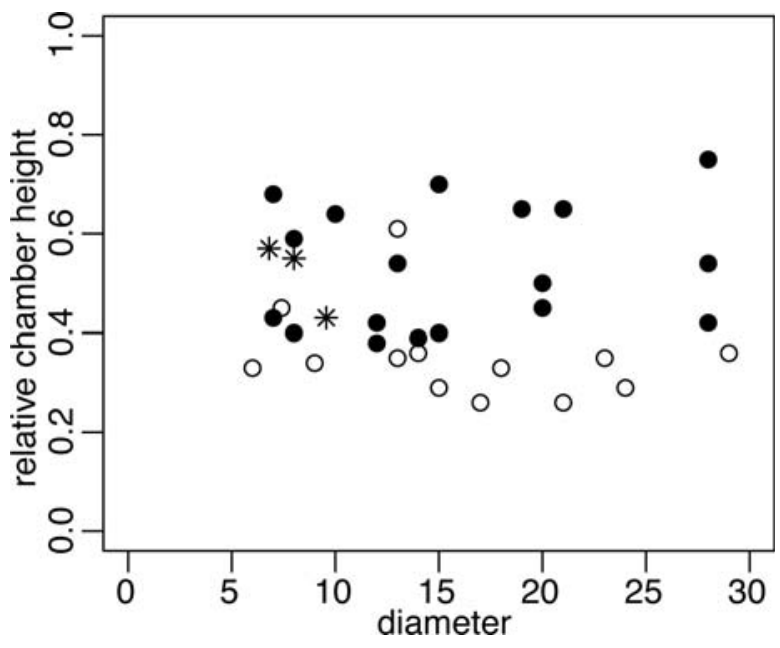

Figure 11. Relative chamber height of specimens of Transorthoceras osmundsbergense n. sp. (black circles) and Isorthoceras dalecarlense n. sp. (white circles), stars denote indet. fragments (see Fig. 10).

\section{Proteoceratidae gen. et sp. indet.}

Figures 6D, F

Material. Five specimens PMU 25266-25270 from nautiloid bed, top of Glisstjärn Formation, Hirnantian, Late Ordovician and horizon, Osmundsberget quarry, Rättvik Municipality, Siljan District, Sweden (locality Osmundsberget 1 of Ebbestad \& Högström 2007b).

Description. Orthoconic specimens with angle of expansion $4-5^{\circ}$ (specimen PMU 25266 with diameter 14.6-16 mm, length $23 \mathrm{~mm}$; specimen PMU 25267 with diameter $8.1-10 \mathrm{~mm}$, length $15 \mathrm{~mm}$ ). Conch surface poorly preserved but apparently smooth. Conch cross section circular. Sutures directly transverse with distance $0.17-0.22$ of corresponding conch cross section. Septal perforation of specimen PMU 25270 central with diameter $3 \mathrm{~mm}$ at conch cross section $14 \mathrm{~mm}$ ( 0.21 of conch cross section). Septal necks loxochoanitic, relatively long with $1.3 \mathrm{~mm}$ at chamber height $4 \mathrm{~mm}$ (c. 0.3 of chamber height) in same specimen. Siphuncular segments expanded with widest diameter of $2.5 \mathrm{~mm}$ at adoral half of each segment at diameter $9 \mathrm{~mm}$ in specimen PMU 25267, and with relatively short suborthochoanitic septal necks and heavy parietal deposits.

Remarks. The five fragments are similar in having a narrow chamber spacing of 5-6 chambers per length similar to conch cross section and a smooth conch. This is different from Transorthoceras osmundsbergense and Isorthoceras dalecarlense which have 2-3 chamber in a distance similar to the corresponding conch cross section. The relatively long, loxochoanitic septal necks of specimen PMU 25270 differ considerably from the short suborthochoanitic septal necks of specimen PMU 25267 but septal spacing and the similarity in general conch shape are provisionally interpreted as evidence that both fragments belong to the same species. This species would be characterized by 
an ontogenetic change of the shape of the siphuncular segments from expanded in early stages to tubular in late stages, which is typical for the Proteoceratidae.

However, the fragmentary character of the specimens and the uncertainty in the reconstruction of the different growth stages allows no better taxonomic determination.

Order Tarphycerida Flower \& Kummel, 1950 Family Discoceratidae Dzik, 1984

\section{Discoceras Barrande, 1867}

Type species. Clymenia antiquissima Eichwald, 1842, from Vormsi Regional Stage (Lyckholm), Katian, Late Ordovician, Kärdla, Hiiumaa Island, Estonia; by original designation.

Diagnosis. Gradually expanding, ribbed or smooth forms characterized by slight or moderate impression and subquadrate whorl section; siphuncle central in initial half-volution, marginodorsal in succeeding 1.5 to 2 whorls, subdorsal at maturity (from Furnish \& Glenister 1964).

\section{Discoceras siljanense $\mathbf{n}$. sp.}

Figures $7 \mathrm{C}, 12$

Etymology. The name refers to the type region, the Siljan District in Dalarna, Sweden.

Holotype. PMU 25271.

Type locality. Osmundsberget quarry, Rättvik Municipality, Siljan District, Sweden (locality Osmundsberget 1 of Ebbestad \& Högström 2007b).

Type horizon. Nautiloid bed, top of of Glisstjärn Formation, Hirnantian, Late Ordovician.

Material. One additional specimen, PMU 25272, from type locality and horizon (locality Osmundsberget 5 of Ebbestad \& Högström 2007b).

Diagnosis. Rapidly expanding Discoceras with WER of 1.83. Conch cross section subquadratic with shallow imprint zone and WWI of 1.54. Ornamented with sharp prominent sometimes bifurcating ribs which form deep angular hyponomic sinus. Subordinate secondary
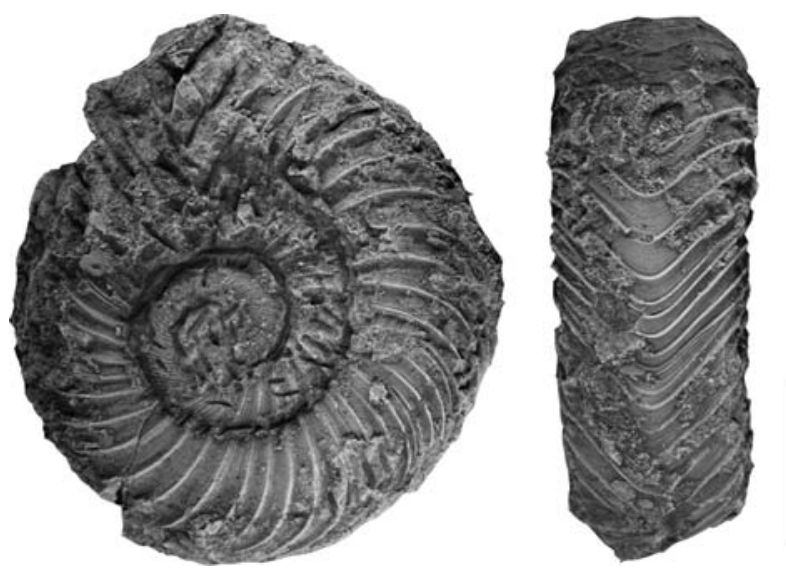

Figure 12. Discoceras siljanense n. sp., PMU 25271 from the nautiloid bed at the top of Glisstjärn Formation, Hirnantian, Late Ordovician and horizon, Osmundsberget quarry, Rättvik Municipality, Siljan District, Sweden. Scale bar $10 \mathrm{~mm}$. transverse ridges occur in later growth stages. D. antiquissimum differs in having fewer and more pronounced ribs and a clearly lower WER of 1.78. D. boreale Sweet, 1958 displays more than 60 ribs per whorl and expands with a WER of more than 2 .

Description. Holotype is fragmented phragmocone with diameter of $31 \mathrm{~mm}$, height of last whorl $8 \mathrm{~mm}$ (WER: 1.83 ), width of last whorl 12.35 (WWI: 1.54), subquadratic whorl cross section, and shallow imprint zone. Ventrally nearly flattened with very shallow, broad curvature. Ornamented with c. 40 prominent irregularly spaced, sharp ribs per whorl. Ribs form deep angular hyponomic sinus. More than 10 subordinate irregularly spaced transverse ridges run parallel toward ribs per cycle of annulation. Ribs and subordinate lirae bifurcate ventrally in some cases. Ribs more closely spaced and without secondary transverse lirae in juvenile growth stages of less than $12 \mathrm{~mm}$.

Specimen PMU 25272 is a weathered specimen with diameter of $36 \mathrm{~mm}$, height of last whorl $9 \mathrm{~mm}$. The width of the last whorl is obscured due to weathering.

Remarks. The internal characters of the species are not known. However, the strong similarity of the general conch shape with the type species of Discoceras, D. antiquissimum, justifies the generic determination. An undescribed, unnumbered conch impression from Siuge, Estonia, Siuge Member, Porkuni Regional Stage in the stratigraphic collection of the Paleozoology department of the Swedish Natural History Museum, Stockholm, Sweden is very similar to Discoceras siljanense n. sp. in general conch shape, but differs in having a slightly higher number of ribs and a clearly higher rate of whorl expansion. Discoceras boreale from the Middle Ordovician upper Elnes Formation of the Oslo Region is similar to D. siljanense with respect to the shape of the ribs but differs in having a higher expansion rate and a higher number of less pronounced ribs.

\section{Acknowledgements}

BK was a Feodor-Lynen Fellow of the Alexander von Humboldt Stiftung during his work in Stockholm and Uppsala. The visit to Stockholm by BK was supported by SYNTHESYS SE-TAF 5040. ÅM acknowledge funding from Leksand municipality towards field work in the Siljan District. Svenska Mineral AB granted access to Osmundsberget quarry. We are grateful of David Evans (Peterborough, UK) and an anonymous second reviewer for the critical review of the manuscript. This is a contribution to the IGCP Project no. 503 "Ordovician Palaeogeography and Palaeoclimate”.

\section{References}

Angelin, N. P. \& Lindström, G. 1880. Fragmenta Silurica. Samson and Wallin, Stockholm.

Apollonov, M. K., Bandaletov, S. M. \& Nikitin, I. F. 1980. Granica Ordovika i Silura v Kazahstane. Nauka, Alma Ata.

Balashov, E. G. 1962. Nautiloidei ordovika sibirskoi platformy. Izdatel'stvo Leningradskogo Universiteta, St. Petersburg. 
Barrande, J. 1865-74. Système Silurien du centre de la Bohême, I. ère partie, Recherches Paléontologiques, vol. II, Classe de Mollusques, Ordre des Céphalopodes. Charles Bellmann, Prague.

Barrande, J. 1877. Système Silurien de la centre de la Bohême, I. ère partie: Recherches Paléontologiques, Volume II, Classe de Mollusques, Ordre des Cephalopodes, supplement et serie tardive. Charles Bellmann, Prague, Supplement 1 and 2.

Barskov, I. S. 1980. Klass Cephalopoda. Golovonogie. In Apollonov, M. K., Bandaletov, S. M., \& Nikitin, I. F. (eds). Granica Ordovika i Silura v Kazahstane. Nauka, Alma Ata: pp. 81-85.

Bassler, R. S. 1919. The Cambrian and Ordovician Deposits of Maryland. In Bassler, R. S. (ed.). Systematic Paleontology. Mollusca. Maryland Geological Survey, Baltimore: pp. 277-331.

Bergström, S. M., Saltzman, M. M. \& Schmitz, B. 2006. First record of the Hirnantian (Upper Ordovician) $\delta 13 \mathrm{C}$ excursion in the North American Midcontinent and its regional implications. Geological Magazine 143: 657-678.

Bruguière, J. G. 1789. Histoire naturelle des vers. Volume 1, part 1. Encyclopedie methodique 6. Charles-Joseph Panckoucke, Paris.

Catalani, J. A. 1987. Biostratigraphy of the Middle and Upper Ordovician cephalopods of the Upper Mississippi Valley area. In Sloan, R. E. (ed.). Middle and Late Ordovician lithostratigraphy and biostratigraphy of the Upper Mississippi valley. - Minnesota Geological Survey Report of Investigations 35: 187-189.

Chang, Jih-tung. 1957. Fossil Nautiloid Cephalopoda in the Yangtzeela Poloi Zone of the Middle Ordovician of Chanyang, Hupei. Acta Palaeontologica Sinica 5: 33-61.

Chen, Jun-yuan \& Zou, Xi-peng. 1984. Ordovician cephalopods from the Ordos area, China. - Memoirs of the Nanjing Institute of Geology and Palaeontology 20: 33-111.

Clarke, J. M. 1897. The Lower Silurian cephalopoda of Minnesota. Minnesota Geology and Natural History Survey 3 (2): 761-812.

Cumings, E. R. 1908. The stratigraphy and paleontology of the Ordovician rocks of Indiana. - Indiana Department of Natural Resources 32nd Annual Report: 605-1188.

Dzik, J. 1984. Phylogeny of the Nautiloidea. - Acta Palaeontologia Polonica 45: 3-203.

Ebbestad, J. O. R. \& Högström, A. E. S. 2007a. Ordovician of the Siljan district, Sweden. In Ebbestad, J. O. R., Wickström, L. M. \& Högström, A. E. S. (eds). 9th meeting of the Working Group on Ordovician Geology of Baltoscandia. Field guide and Abstracts. SGU Rapporter och Meddelanden 128: 7-78.

Ebbestad, J. O. R. \& Högström, A. E. S. 2007b. Locality descriptions, the Siljan District, Sweden. In Ebbestad, J. O. R., Wickström, L. M. \& Högström, A. E. S. (eds). 9th meeting of the Working Group on Ordovician Geology of Baltoscandia. Field guide and Abstracts. - SGU Rapporter och Meddelanden 128: 52-58.

Ebbestad, J. O. R., Frisk, A. M. \& Högström, A. E. S. 2007. Mass concentration of nautiloids and associated fauna in the Late Ordovician at Osmundsberget, Siljan district, Dalarna. In Ebbestad, J. O. R., Wickström, L. M. \& Högström, A. E. S. (eds.). 9th meeting of the Working Group on Ordovician Geology of Baltoscandia. Field guide and Abstracts. - SGU Rapporter och Meddelanden 128: 110 .

Eichwald, E. de 1842. Die Urwelt Russlands durch Abbildungen erlaeutert. 2. Heft. Neuer Beitrag zur Geognosie Esthlands und Finlands. Akademie der Wissenschaften, St. Petersburg.

Eichwald, E. de 1860. Lethaea Rossica ou Palóntologie de la Russie. Schweizerbart, Stuttgart.

Evans, D. H. 1993. The cephalopod fauna of the Killey Bridge Formation (Ordovician, Ashgill), Pomeroy, County Tyrone. - Irish Journal of Earth Sciences 12: 155-189.

Evans, D. H. 2002. Some additional Ordovician and Silurian cephalopods from Ireland. - Special Papers in Palaeontology 67: 77-96.

Flower, R. H. 1946. Ordovician cephalopods from the Cincinnati region. Part 1. - Bulletins of American Paleontology 26(116): $3-$ 547.
Flower, R. H. 1955. New Chazyan orthocones. - Journal of Paleontology 29: $808-830$.

Flower, R. H. 1962. Notes on the Michelinocerida. - New Mexico Bureau of Mines and Mineral Resources Memoir 10: 21-40.

Flower, R. H. \& Kummel, B. 1950. A classification of the Nautiloidea. - Journal of Paleontology 24: 604-616.

Flower, R. H. 1946. Ordovician cephalopods from the Cincinnati region. Part 1. - Bulletins of American Paleontology 26 (116): 3547

Foerste, A. F. 1914. The Rogers Gap Fauna of Central Kentucky. Journal of the Cincinnati Society of Natural History 21: 109-156.

Foerste, A. F. 1924. Notes on American Paleozoic cephalopods. - Denison University Bulletin, Journal of the Scientific Laboratories 20: 193-268.

Foerste, A. F. 1926. Actinosiphonate, Trochoceroid and other cephalopods. - Denison University Bulletin, Journal of the Scientific Laboratories 21: $285-383$

Foerste, A. F. 1932. Black River and other cephalopods from Minnesota, Wisconsin, Michigan, and Ontario (Part 1). - Journal of Scientific Laboratories of Denison University 27: 47-136.

Foerste, A. F. 1936. Cephalopods from the Upper Ordovician of Percé, Quebec. - Journal of Paleontology 10: 373-384.

Foord, A. H. 1888. Catalogue of the fossil Cephalopoda in the British Museum (Natural History). British Museum, London.

Frey, R. C. 1995. Middle and Upper Ordovician Cephalopods of the Cincinnati Region of Kentucky, Indiana, and Ohio. - United States Geological Survey Professional Paper 1066P: 1-119.

Frye, M. W. 1982. Upper Ordovician (Harjuan) nautiloid cephalopods from the Boda Limestone of Sweden. - Journal of Paleontology 56: $1274-1292$.

Frye, M. W. 1987. Upper Ordovocian (Harjuan) oncoceratid nautiloids from Boda Limestone, Siljan District, Sweden. - Geologiska Föreningens i Stockholm Förhandlingar 109: 83-99.

Furnish, W. M. \& Glenister, B. F. 1964. Nautiloidea-Tarphycerida. In Teichert, C. (ed.). Treatise on Invertebrate Paleontology, Part K, Mollusca 3. Geological Society of America and the University of Kansas Press, Boulder, Colorado: pp. K343-K368.

Grabau, A. W. \& Shimer, H. W. 1910. North American index fossils, Invertebrates. A. G. Seiler \& Company, New York.

Grabau, A. W. 1922. Ordovician fossils of North China. - Palaeontologia Sinica, Series B 1 (1): 3-95.

Hall, J. 1847. Natural history of New York, Paleontology, Volume 1, containing descriptions of the organic remains of the lower division of the New-York System (equivalent of the Lower Silurian rocks of Europe). Van Benthuysen, Albany, New York.

Hall, J. 1861. Report of the superintendent of the (Wisconsin) Geological Survey, exhibiting the progress of the work, January 1, 1861 (including the descriptions of new species of fossils from the investigations of the Survey). E. A. Calkins and Co, Madison, Wisconsin.

Hatfield, C. B. 1968. Stratigraphy and paleoecology of the Saluda Formation, Cincinnatian, in Indiana, Ohio, and Kentucky. - Geological Society of America, Regional Studies Special Paper 95: 1-34.

Holland C. H. \& Copper, P. 2008. Ordovician and Silurian nautiloid cephalopods from Anticosti Island: traject across the O/S Mass extinction boundary. - Canadian Journal of Earth Sciences 48: 1015-1038.

Hyatt, A. 1884. Genera of fossil cephalopods. - Proceedings of the Boston Society of Natural History 22: 253-338.

James, J. F. 1886. Cephalopoda of the Cincinnati Group. - Journal of the Cincinnati Society of Natural History 8: 236-253.

Korn, D. \& Klug, C. 2003. Morphological pathways in the evolution of Early and Middle Devonian ammonoids. - Paleobiology 29: 329-348.

Kröger B., Servais T. \& Zhang Yunbai. 2009. The Origin and Initial Rise of Pelagic Cephalopods in the Ordovician. - PLoS ONE 4 (9): e7262. doi:10.1371/journal.pone.0007262. 
Kröger, B. 2007. Concentrations of juvenile and small adult cephalopods in the Hirnantian cherts (Late Ordovician) of Porkuni, Estonia. - Acta Palaeontologica Polonica 52: 591-608.

Kröger, B. \& Isakar, M. 2006. Revision of annulated orthoceridan cephalopods of the Baltoscandic Ordovician. - Fossil Record 9 (1): $139-165$.

Kuhn, O. 1940. Paläozoologie in Tabellen. Fischer Verlag, Jena.

Marek, J. 1999. Ordovician cephalopods of the Prague Basin (Barrandian area, Czech Republic): a review. - Acta Universitatis Carolinae-Geologica 43: 413-416.

McCoy, F. 1844. Synopsis of the Characters of the Carboniferous Limestone Fossils of Ireland. University Press, Dublin.

Miller, S. A. 1877. The American Palaeozoic Fossils: a catalogue of the genera and species with names of authors, dates, places of publication, groups of rocks in which found, and the etymology and signification of the words and an introduction devoted to the stratigraphical geology of the Palaeozoic rocks. Published privately, Cincinnati, Ohio.

Mutvei, H. 1957. On the relations of the principal muscles to the conch in Nautilus and some fossil nautiloids. - Arkiv för Mineralogi och Geologi 2: 219-254.

Niko, S. 2008. Isorthoceras wahlenbergi, a new Late Ordovician cephalopod from the Boda Limestone of Dalarna, Sweden. - Paleontological Research 12: 195-198.

D’Orbigny, A. D. 1850. Prodrome de Paléontologie stratigraphique universelle des animaux mollusques \& rayonées faisant suite au cours élémentaire de paléontologie et géologie stratigraphique. Victor Masson, Paris.

Portlock, J. E. 1843. Report on the Geology of the County of Londonderry and of parts of Tyrone and Fermanagh. Andrew Milliken, Dublin.

Purnell, L. R. 1968. Catalog of the Type specimens of Invertebrate Fossils. Part I: Paleozoic Cephalopoda. - United States National Museum Bulletin 262: 1-198.

Rasmussen, C. M. Ø., Ebbestad, J. O. R. \& Harper, D. A. T. 2010. Unravelling a Late Ordovician pentameride (Brachiopoda) hotspot from the Boda Limestone, Siljan district, central Sweden. - Geologiska Föreningens i Stockholm Förhandlinger 129: 133-140.

Roemer, C. F. 1861. Die fossile Fauna der silurischen DiluvialGeschiebe von Sadewitz bei Oels in Niederschlesien - Eine palaeontologische Monographie. Robert Nischkowsky, Breslau.

Ruedemann, R. 1912. The Lower Siluric shales of the Mohawk Valley. - New York State Museum Bulletin 162: 1-123.

Ruedemann, R. 1926. The Utica and Lorraine formations of New York. Part 2. Systematic Paleontology. No. 2. Mollusks, Crustaceans and Eurypterids. - New York State Museum Bulletin 272: $1-168$.

Schmidt, F. 1858. Untersuchungen über die Silurische Formation von Ehstland, Nord-Livland und Ösel. - Archiv für die Naturkunde
Liv-, Ehst- und Kurlands, 1. Serie (Mineralogische Wissenschaften, nebst Chemie, Physik und Erdbeschreibung) 2: 1-248.

Schmitz, B. \& Bergström, S. M. 2007. Chemostratigraphy in the Swedish Upper Ordovician: Regional significance of the Hirnantian $\delta 13 \mathrm{C}$ excursion (HICE) in the Boda Limestone of the Siljan region. - Geologiska Föreningens i Stockholm Förhandlingar (GFF) 129: 133-140.

Sowerby, J. 1816. The Mineral Conchology of Great Britain; or Coloured Figures and Descriptions of those Remains of Testaceous Animals or Conchs which have been Preserved at Various Times and Depths in the Earth. Benjamin Meredith, London.

Strand, T. 1934. The Upper Ordovician Cephalopods of the Oslo Area. - Norsk geologiske Tidsskrift 14: 1-117.

Stumbur, H. 1956. O nautiloidea Kohilaskogo Jarusa (Verhnij Ordovik Pribaltiki). - Tartu Riikliku Ülikooli Toimetised 42: 176-185.

Suzuki, Y., Shiino, Y. \& Bergström, J. 2009. Facies transition of Hirnantian sequence of the Boda Limestone, with brief reports on association trilobites. - Geologiska Föreningens i Stockholm Förhandlingar (GFF) 131: 299-310.

Sweet, W. C. 1958. The Middle Ordovician of the Oslo region of Norway. 10. Nautiloid cephalopods. - Norsk Geologiske Tidsskrift 31: $1-178$.

Sweet, W. C. 1964a. Oncocerida. University of Kansas Press, Boulder, Colorado.

Sweet, W. C. 1964b. Nautiloidea-Orthocerida, University of Kansas Press, Boulder, Colorado.

Teichert, C. 1930. Die Cephalopoden-Fauna der Lyckholm-Stufe des Ostbaltikums. - Paläontologische Zeitschrift 12: 264-312.

Thorslund, P. 1935. Über den Brachiopodenschiefer und den jüngeren Riffkalk in Dalarne. - Nova Acta Regio Societas Scientiarum Upsaliensis 4: 1-50.

Titus, R. \& Cameron, B. 1976. Fossil communities of the lower Trenton Group (Middle Ordovician) of central and northwestern New York State. - Journal of Paleontology 50: 1209-1225.

Troedsson, G. T. 1926. On the Middle and Upper Ordovician faunas of northern Greenland. I. Cephalopods. - Meddeleser om Grønland 71: 1-157.

Twenhofel, W. H. 1916. The Silurian and high Ordovician strata of Estonia, Russia and their faunas. - Bulletin of the Museum of Comparative Zoology at Harvard College, Geological Series 10 (3): 290-354

Wilson, A. E. 1961. Cephalopoda of the Ottawa formation of the Ottawa-St. Lawrence Lowland. - Bulletin of the Geological Survey of Canada 67: 1-106.

Zhuravleva, F. A. 1961. Some nautiloids from Podolia. - Paleontologicheskij Zhurnal 1961 (4): 55-59.

Zou, Xi-peng. 1988. Ordovician nautiloid faunas from Lunshan, Jurong, Jiangsu. - Acta Palaeontologica Sinica 27: 309-330. 